\title{
DETERMINANTS OF SAVINGS BEHAVIOR IN PAKISTAN: LONG RUN - SHORT RUN ASSOCIATION AND CAUSALITY
}

\author{
Fawad AHMAD ${ }^{1}$
}

DOI: 10.1515/tjeb-2015-0011

\begin{abstract}
The existing studies on private savings have mostly investigated the long run and short association of different variables with private savings, whereas no known study has investigated both long run and short run causality of variables against private savings by using data of Pakistan. The current study used time series data of Pakistan over the period of 1972 to 2012 and employed long run cointegration test, first normalized equation for long run association, vector error correction model for short run association, Toda Yamamoto technique for long run causality and Granger causality test for short run causality. The results suggest that GDP per capita, inflation rate, financial development, dependency ratio and fiscal development have impact on the private savings rate in Pakistan. The findings of the current study can be used to increase the private savings' rate. In the long run government can increase the private savings by controlling fiscal deficit and promoting the investment by private investors. Whereas, in the short run, government can increase the deposit rate to increase the private savings. The current study is unique in its nature as it simultaneously provides the long run and short run causality and association and can contribute significantly in improving savings rate in developing economies like Pakistan.
\end{abstract}

Keywords: $\quad$ Savings, Life Cycle, Precautionary Savings, Financial Development, Absolute Income Hypothesis.

JEL Classification: D1, H6, H8, J6.

${ }^{1}$ Lecturer, FAST School of Management, NUCES-FAST, Peshawar Campus, Pakistan. 


\section{Introduction}

The economic growth and performance of the Pakistan economy was significantly weaker as compared to the other rapidly growing Southeast Asian economies during 1990s and 2000s. The Southeast Asian countries have made substantial progress in improving their living standards, economic growth, per capita income and infrastructure, whereas the growth and performance of the Pakistan economy remained virtually stagnant over last two decades. This difference in economic growth and performance can be mainly attributed to the low savings and interest rate in Pakistan (Haque et al., 1994). The savings rate directly relates to the level of consumption and investments by the individuals and investors, capital account, current account, growth rate, exchange rate and interest rate. Private savings is also important from the social perspective that individuals should have certain level of life standard and maintain it after retirement; therefore during the working life savings are made to maintain stable level of consumption. Thus private savings has both economic and social importance in the economy; therefore government and private sector encourages the savings behavior by offering old age benefits plans and other savings policies to the working class. As a result economic activities in the economy and social protection to the individuals are assured in long run.

Existing literature has analyzed various determinants of private savings behavior in Pakistan but the econometric models presented in existing studies are not fully developed. These models do not account for the non-measureable variables that may have significant impact on savings (Kazmi, 2001).

The literature on savings behavior in Pakistan is not extensive, few of the previous studies have analyzed the impact of different macroeconomic and demographic variables on savings behavior, for instance; Qureshi (1981); Khan et al., (1992); Kazmi (1993); Siddiqui and Siddiqui (1993); Khan et al., (1994); Husain (1996); Ahmad \& Asghar (2008); Ahmad et al., (2006); and Chaudhry et al., (2010). In the last decade no significant contribution was made in the private savings behavior literature of Pakistan. Therefore the purpose of the current study is to investigate the determinants of private savings by using GDP per capita income, inflation rate, financial development, dependency ratio, exchange rate, industrial production, M2 and fiscal deficit as explanatory variables.

From the point of view of the methodology, most of the existing studies have used ordinary least square (OLS) and ARDL (Jongwanich, 2010) long run and short run association models to investigate the determinants of private savings, whereas no known study has investigated the long run or short run casualty between determinants and savings behavior. Thus, from the point of view of the methodology, the current study has two main objectives. First to investigate the long run and short term association between savings behavior and its determinants by using the long run co-integration test, first normalized equation and vector error correction model;

DE GRUYTER OPEN
Timisoara Journal of Economics and Business | ISSN: 2286-0991 | www.tjeb.ro Year 2015 | Volume 8 | Issue 1 | Pages: 103 - 136 
Ahmad, F. (2015).

Determinants of Savings Behavior in Pakistan: Long Term- Short Term Association and Causality

second, the short run and long run causality is checked by using the Granger causality test and the Toda \& Yamamoto (1995) technique, respectively.

The current study is divided into six main sections, section 1 provides the introduction of the study, section 2 provides the detailed literature on the savings behavior, section 3 provides the explanatory variables used in the study, section 4 provides the research methodology used, sections 5 presents the results and findings of the study and section 6 presents the conclusions and policy related implications of the study.

\section{Literature Review}

The literature on saving behavior on the basis of data used can be divided into four parts, first, savings theories, second, the literature on studies using individual country data, third, the literature on studies using cross-country data and lastly, the literature on studies of Pakistan.

Ramsey (1928) attempted to determine how much an infinitely lived consumers would consume and save at every point in time during their lifetime. The amount saved would not only be beneficial to the consumer for future needs but also to the economy and society. The saved amount adds to the economy physical capital and is used for the investment in the economy. In the long run this leads to the growth in economic activities in the economy/country. Thus the reduction of current consumption leads to the growth in the future consumption and investment. Ramsey (1928) further argued that the consumer will save and scarifies current consumption untill the point when current scarifies in consumption in term of units is equal to benefits or happiness of future unit consumption. Ramsey (1928) suggested that in the short run saving rate determine the speed of capital accumulation and growth in economy and as a result economy gains a stable state in long run. Due to some mathematical difficulty and complexity Ramsey's theory did not get much appreciation. Later on Cass, Tjalling and Koopmans in 1960s further developed Ramsey theory into a theory of long run term growth for a decentralized market economy.

Hayek (1932) proposed the Forced savings concept which suggested that economic conditions in which the consumption of individuals are less than disposable income not because of Voluntary savings but due to the unavailability of goods. The individuals with high disposable income pay more in order to get the available goods, resulting in the high prices of goods. Thus the government should force the savings of individuals towards the production of goods, because in the free economy this leads to an increase in the prices of goods..

Keynes (1936) presented the Absolute Income hypothesis, proposing the association between income and consumption and suggested that the real consumption is the function of the real disposable income and the income net of taxes. The increase in the real income leads to growth

DE GRUYTER OPEN
Timisoara Journal of Economics and Business | ISSN: 2286-0991 | www.tjeb.ro Year 2015 | Volume 8 | Issue 1 | Pages: 103 - 136 
Ahmad, F. (2015).

Determinants of Savings Behavior in Pakistan: Long Term- Short Term Association and Causality

in consumption but not with the same rate, resulting in the excess of income as compared to consumption, suggesting that saving is the function of income. Pigou (1943) suggested that during deflation because of the growth in real balances of wealth, household consumption increases. This increase in consumption is caused by the growth in production and unemployment and termed this effect as the Real balance effect.

The relative income hypothesis proposed by Dusenberry (1949) stated that the utility (satisfaction) derived by individuals given at current consumption level is mainly derived from the status in the society rather than from the absolute level of income. This concludes that the individual consumption is mainly influenced by their current status, relative consumption and name in the society. Furthermore, the income distribution has significant influence on the individual saving rate and two main findings can be derived from Dusenberry's (1949) relative income hypothesis. First, aggregate savings and income are dependent on each other; second, the aggregate savings depend on the individual status level and income distribution in the economy.

The life cycle model of savings analyzed the patterns of individual consumption and predicted that the consumption of individuals depends on the expectation of the long term earnings (income) and saving patterns, to level out the consumption over the long period of time. As individual income tends to fluctuate over the period of individual life, savings is determined by a period of individual life in which they save more than the disposable income. Thus individuals in their life time first act as savers during high income times (while working) and act as dissever in low income time (during retirement), therefore individuals smooth out future consumption by using current earnings.

The permanent income hypothesis suggests that the stable income leads to the constant consumption by the individuals, with the increase in income level or higher future income individual saving declines. The permanent income hypothesis also distinguishes between temporary and permanent income. The temporary changes in income are met by smoothing of consumption, thus today savings will be used for future increased spending. Thus it can be concluded that temporary changes in income have significant impact on current spending but marginal impact on the future spending. On the other hand permanent income change results in the increased savings as there is no reason for savings with future increase in income.

Leland (1968) suggested the Precautionary saving hypothesis, which proposed that despite of the savings for the smoothing of future consumption individuals have additional motives for savings i.e. to secure against the uncertainty associated with risk management product offering of insurance market. Thus individual would not be able to secure themselves against the future economic uncertainty. They in order to secure against future lower income keep aside a certain amount as precautionary reserves, by current lower consumption. Furthermore it concludes that uncertainty with the future income and incompleteness of the insurance market has significant influence on the precautionary savings of individuals.

\section{DE GRUYTER} OPEN 
Ahmad, F. (2015).

Determinants of Savings Behavior in Pakistan: Long Term- Short Term Association and Causality

The Buffer stock theory suggested that individuals hold assets to smooth out and to secure their future consumption level against unpredictable fluctuations in future income. The main reason for the accumulation behavior is the prediction of the consumers relating to the future income uncertainty, resulting in the prudence, impatience and uncertain behavior of consumers. The impatience behavior refers to the inability of the consumers to finance current consumption by using future income for repayment, therefore uncertainty relating to future income leads to reduction in the current consumption and prudence will force the consumer increase in precautionary savings for future. Carroll (1992) argued that impatience and prudence result in the specific target wealth for the consumers. Whenever the consumer wealth is above the target level then impatience dominates the prudence leading to the increase in consumption and the lack of saving. Whereas, whenever wealth is below the target level then prudence dominates the impatience of consumers, resulting in the precautionary savings for the future.

Lambert and Hoselitz (1963) compiled the findings of studies conducted in Vitenam, Pakistan, India, the Philippines, Hong Kong, Malaysia and Sri-Lanka. Similarly, Snyder (1974) analyzed the previous studies from the econometric models point of view, afterwards the saving behavior has become an area of interest for research.

Cardenas and Ecsobar (1998) found results in the favor of permanent income hypothesis by suggesting that national savings respond to the changes in output. They further concluded that high government spending leads to the decline rate of national savings; national savings are perfectly correlated with changes in investments; national savings granger causes growth; private savings significantly declines with urbanization and age dependency; and finally they argued that the recent decline in private saving is mainly because of higher taxation rates.

Loayza and Shankar (2000) studied the private savings trend in India and employed errorcorrection model. They found significant positive association of per capita income, real interest rate and agriculture share in GDP with private savings, whereas they found significant negative association of financial development, inflation and dependency ratio with the savings rate. Later on, Athukorola and Sen (2003) conducted the same study by using data on India and confirmed the findings of Loayza \& Shankar (2000) by suggesting that excluding changes in the external trade, macroeconomic variables such as real deposits rate, rate of growth, inflation and banks financial services spread are positively correlated with the savings.

Ozcan et al., (2003) investigated the private saving behavior factors by using Turkey data and found that inflation rate, financial depth and income level are positively associated with private savings. Unlike other studies, Athukorala \& Kunal (2003) investigated the impact of factors such as the impact of population dynamics, social security contributions, and growth in disposable income, financial reforms and credit availability by using the standard life cycle savings framework. Social security contributions, the aging of population and the availability of credit play a significant role in determining the saving performance. They further concluded that

\section{DE GRUYTER OPEN}

Timisoara Journal of Economics and Business | ISSN: 2286-0991 | www.tjeb.ro Year 2015 | Volume 8 | Issue 1 | Pages: 103 - 136 
Ahmad, F. (2015).

Determinants of Savings Behavior in Pakistan: Long Term- Short Term Association and Causality

inflation is negatively associated with savings, whereas the interest rate is significantly positively associated with savings. Qin (2003) studied the saving behavior of mainland China and concluded that the expected future saving potential was the main determinant of savings in banks. Furthermore the interest rate and precautionary motives can also influence the saving motives of individuals in both Taiwan and mainland China.

Hondroyiannis (2004) analyzed the long term saving behavior of Greek households by applying the co-integration technique and data over the period of 1961 to 2000 . The results showed that in long run the saving function is sensitive to old dependency ratio, liquidity, real interest rate, fertility changes and public finance.

Ang (2009) examined the determinants of household savings in India and China by modifying the life cycle model to account for the expected benefits of pension saving. The results supported the prediction of the life cycle model that growth in income and inflation stimulates the growth in household savings, whereas age dependency has the opposite impact on savings. Furthermore, the results suggested that the expected increase in pension benefits tended to encourage the savings in India in the long run, whereas the reverse association was found for China.

Jongwanich (2010) investigated the determinants of household and private savings in Thailand for the period of 1960 to 2004 . The extended version of life cycle model was used to estimate the savings function by using ARDL modeling technique. The independent variables used in the extended life cycle model were growth rate of real per capita income, youth dependency, elderly dependency, inflation, terms of trade, real interest rate and credit constrained. The results proved positive association of economic growth and inflation with domestic and private savings, whereas the availability of credit tends to be negatively associated with the savings rate. The elderly and youth dependency has a negative influence on the household and private savings, the magnitude of the association is far greater for the former than for the latter. Furthermore it was concluded that the fiscal policy is playing an important role in increasing the level of national savings in the economy.

One of the recent studies on the determinants of household saving was conducted by Simleit et al. (2011). The main motivation of their study was to investigate the reasons for the decline in household savings by using South African data. They employed the vector error-correction model and concluded that the interest rate, the upturn business cycle and wealth effect significantly explains the decline in the saving rate. They further suggested that the decline in government and household savings are major fiscal problem for the government. Government can increase the savings by using an effective fiscal policy.

Murshed \& Robin (2012) investigated the impact of the financial liberalization policy on the Bangladesh banking sector by using annual time series data from 1981 to 2008 . They concluded

DE GRUYTER OPEN
108

Timisoara Journal of Economics and Business | ISSN: 2286-0991 | www.tjeb.ro

Year 2015 | Volume 8 | Issue 1 | Pages: 103 - 136 
Ahmad, F. (2015).

Determinants of Savings Behavior in Pakistan: Long Term- Short Term Association and Causality

that the main objective of the financial liberalization is to encourage the domestic saving by increasing the real interest rate has no implication in Bangladesh. They found insignificant positive association between domestic savings and the increase in the real interest rate.

Larbi (2013) investigated the determinants of private savings by using the co-integration test. Larbi (2013) concluded that per-capita income, financial liberalization, fiscal deficit and inflation have positive impact on the private savings rate in Ghana. The results confirmed the applicability of the Ricardian Equivalence hypothesis in Ghana. Larbi (2013) argued that government spending, improved saving packages and control over fiscal deficit can improve the savings rate in Ghana.

There are numerous existing studies that used cross country data for the analysis of private saving determinants. Doshi (1994) investigated the impact of population growth (age structure and life expectancy period), productivity growth (Gross National Product) and GDP growth on savings by using life cycle framework in 129 countries. The results suggested positive association of life expectancy with savings in less-developed countries whereas negative association was found between life expectancy and savings for high income developed countries. They further found significant influence of demographic variables in Asia, income growth in Latin countries and per capita income in Africa on the savings ratio. Later on Masson et al., (1998) extended the work of Doshi (1994) by investigating the determinants of the private savings of developing and industrial countries. Their results suggested that GDP growth, changes in the terms of trade and real interest rate were found to be positively correlated with savings ratio in both types of countries; however the magnitude of association varied slightly between both countries.

Loayza \& Shankar (2000) worked on the assumption that the saving rate behavior changes across the countries by using a maximum of 150 countries data over the period of 1965 to 1994. The main objective of their study was to investigate the policy and non-policy related variables influence on the saving behavior across the countries. They concluded that (a) the private and national savings trend changes across the countries and time exhibits large variations (b) the private saving rates among countries are highly correlated (c) the saving rate is positively related with growth in per capita income, furthermore income has greater influence on the savings rate in developing countries as compared to developed countries (d) negative association between the savings rate and the dependency ratio supported the life cycle hypothesis (e) the positive influence of the inflation rate on the savings rate provided support for the precautionary motive for savings (f) the fiscal policy can be used as moderate effective tool for increasing the saving rate (g) the financial liberation is one of the main determinant of the savings rate, because greater credit availability reduces the future savings motives. Furthermore higher real interest rate and bigger financial institutions cannot stimulate the growth in savings rate.

DE GRUYTER OPEN 
Ahmad, F. (2015).

Determinants of Savings Behavior in Pakistan: Long Term- Short Term Association and Causality

The association between savings and growth was analyzed by Agrawal (2001) in seven countries (Singapore, South Korea, Taiwan, Thailand, Malaysia, India and Indonesia). The results suggested that the decline in the age dependency ratio and the high growth in per capita income contribute to the growth in the saving rate of countries. Agrawal (2001) further concluded that the interest rate is significantly positively associated with saving rate in Malaysia whereas in Thailand and Malaysia it is negatively associated with savings rate.

Sarantis \& Stewart (2001) used the data of Economic Co-operation and Development (OECD) countries to investigate the saving behavior and concluded that credit constraints and demographic variables have significant impact of saving behavior. Furthermore greater financial liberalization and integration reduces the liquidity constraints and leads to the decline in savings. They further concluded that government deficits do not stimulate the growth in savings, which is opposite to the Ricardian Equivalence. Cohn \& Kolluri (2003) used the data of G-7 countries to investigate the determinants of household savings. The main aim of their study was to examine the long run association between the real interest rate, per capita household savings, social security contributions and government savings. Their results suggested positive association between the real interest rate and savings, whereas negative association was found between social security savings and government savings.

Hondroyiannis (2006) used data of European countries to investigate the determinants of private savings. He used life cycle hypothesis to develop association between economic and demographic development with private savings. The results suggested that in long run the savings function is sensitive to liquidity, real disposable income, growth, public finances, dependency ratio, real interest rate, old dependency ratio and inflation.

Salotti (2010) used 18 developed countries data over the period of 1980 to 2005 , to investigate the household savings determinants. Salotti (2010) used two new variables in the household function (i.e. financial and household variables) that are not tested before in any study. The results provided negative association between household savings and wealth. Similarly when other important variables (population, dependency ration and government savings) are added to the model, among wealth only tangible wealth showed marginal negative influence on the household savings. Furthermore, in the case of the USA wealth is not negatively affecting household savings whereas population changes and government savings are negatively associated with household savings. The results further proved that the recent boom of stock and real estate is not the primary factor for the decline in the US household savings.

Thanoon \& Baharumshah (2012) compared the savings behavior in Asia and Latin America by focusing on the role of economic growth and capital inflow. They concluded that economic growth has negative impact on savings rate in Latin America, whereas economic growth is positively associated in Asia. The capital inflow has weak negative long term association with domestic savings in Asia as compared to the Latin America. They further found that both

DE GRUYTER OPEN
110

Timisoara Journal of Economics and Business | ISSN: 2286-0991 | www.tjeb.ro

Year 2015 | Volume 8 | Issue 1 | Pages: 103 - 136 
Ahmad, F. (2015).

Determinants of Savings Behavior in Pakistan: Long Term- Short Term Association and Causality

economic growth and capital inflow significantly explain why the saving behaviors in Asia and Latin America differ in the two regions.

The literature on the savings behavior in Pakistan is not that extensive. For instance, Qureshi (1981) estimated savings as a function of permanent income and transitory income. They showed significant positive impact of call money rate, yield on long term government bonds and average interest rate on savings deposits with scheduled banks.

Khan et al., (1992) rejected the Harberger-Laursen-Metzler effect in the case of Pakistan and proved significant positive association of interest rate on savings. Kazmi (1993) investigated the factors that are responsible for the differential in savings rate of India and Pakistan and concluded that differences in the national savings level is due to the difference in the real GNP growth rate, population growth, government expenditure on defense and education, level of imports and exports, external aid, inflation, taxes and interest rate. On the other hand Siddiqui \& Siddiqui (1993) examined the impact of economic and demographic variables on the savings behavior in Pakistan. They considered physical assets, human capital, household age, income and size. They concluded that the increase in population has significant negative impact on savings and unconsumed goods and assets are more responsive to the income change.

Khan et al. (1994) investigated the determinants of private savings rate in Pakistan by using a variety of factors. They reported strong positive impact of per capita GNP on private savings. They found that change in the terms of trade, the openness of the economy and the real interest rate positively influence the national savings and further concluded that debt to GNP ratio and dependency ratio have adverse impact on the national savings.

Husain (1996) empirically analyzed the long-run private saving behavior in Pakistan and concluded that financial deepening is mainly responsible for much of the rise in the private savings and suggested that the decline in the population growth rate and the financial development can contribute towards increases in the private savings rate in the country.

Ahmad and Asghar (2008) investigated the savings behavior in Pakistan by dividing the data into rural and urban data and by using the OLS. They suggested that savings in Pakistan is influenced by wealth, education, current employment status, age and dependency ratio, whereas household income also plays a very important role in the savings behavior.

Ahmad et al. (2006) investigated the household savings behavior of in Pakistan by using time series data for the period of 1972 to 2003 and employed the Johansen-Juselius co-integration technique. They concluded that growth rate, per capita income and interest rate has significant positive impact on household savings, whereas dependency ratio and inflation have significant

DE GRUYTER OPEN
Timisoara Journal of Economics and Business | ISSN: 2286-0991 | www.tjeb.ro Year 2015 | Volume 8 | Issue 1 | Pages: 103 - 136 
Ahmad, F. (2015).

Determinants of Savings Behavior in Pakistan: Long Term- Short Term Association and Causality

negative influence on household savings. They further argued that the government should develop effective polices for the enhancement and growth of household savings.

Sajid and Sarfraz (2008) examined the causality of savings and economic growth in Pakistan. They suggested a long run association between savings and the output level. They proved unidirectional long run causality from public and private savings to GNP and GDP.

Khan and Hye (2010) investigated the impact of the financial sector reforms on the household savings in Pakistan by using the ARDL approach. They found negative long run association of the financial liberalization index and the real deposit rate with household savings, whereas finding a positive long run impact of the per capita income, agriculture sector GDP and remittances on household savings. They concluded that the economy should not rely totally on the financial liberalization for the growth in household savings, whereas policy makers should take measures to increase the per capita income in order to increase the household savings.

Chaudhry et al., (2010) conducted a study to investigate the short and long run savings behavior in Pakistan. They used time series data over the period of 1972 to 2008 and employed Johansen co-integration and vector error correction model. They concluded that exports, consumer price index, workers remittances, government spending, public loans and interest rate have significant influence in determining national savings in long run. They found significant positive influence of consumer price index, workers remittances, government spending, exports and interest rate on national savings, whereas public loans negatively influenced the national savings in long run. They concluded that the government should increase the level of national savings for debt free economy by using the significant variables influences.

Munir et al. (2011) examined the effect of workers' remittances on the private savings behavior in Pakistan by using the ARDL bounded testing approach. They concluded that the workers' remittances has positive impact on the private savings in the long run and the short run, thus workers remittances are both consumed and saved. Furthermore, the foreign direct investment has negative influence on savings because it does not reach poor households directly.

Farhan and Akram (2011) investigated the influence of the income level on the savings behavior in Pakistan by using the ARDL approach. They used income level, age dependency and inflation as explanatory variables and found significant positive influence of the income level on the savings behavior in both the short and the long run.

Recently, Azam and Shakeel (2012) analyzed the impact of foreign capital inflows on household savings by using OLS. They found significant positive influence of foreign direct investments and foreign remittances on savings and significant negative influence of foreign aid on savings.

DE GRUYTER OPEN
Timisoara Journal of Economics and Business | ISSN: 2286-0991 | www.tjeb.ro Year 2015 | Volume 8 | Issue 1 | Pages: 103 - 136 
Ahmad, F. (2015).

\section{Explanatory Variables}

As discussed in the literature review, the existing studies on savings behavior have used a number of macroeconomic variables that play a significant role in explaining the level of private savings. The explanatory variables used in the current study are GDP per capita income, inflation rate, financial development, dependency ratio, exchange rate, industrial production, M2 and fiscal deficit.

Current study consider following model:

$$
S=f[P C I, I N F, F N D, D R, E R, I P, M 2, F S D]
$$

where $\mathrm{S}$ is private savings, $\mathrm{PCl}$ is GDP per capita (per capita income), INF is inflation rate, FND is financial development, DR is dependency ratio, ER is exchange rate, IP is industrial production, M2 is money supply, FSD is fiscal deficit.

\section{Data and Methodology}

The data used for explanatory variables and private savings is the time series data. For each variable 42 years data was used over the period of 1972 to 2012. The data regarding all the variables was collected from the "Handbook of Statistics of Pakistan 2010" and from the World Bank database.

The current study used the time series technique of co-integration, vector autoregressive and impulse response functions to investigate the long run term and short run term savings behavior in Pakistan. Following there are the standard steps for the time series econometrics (i) test the presence of unit root (ii) Selection of optimal lag length and long run co-integration test (iii) Vector Auto Regression (VAR) estimation (iv) impulse response function. For the proper specification and estimation of VAR, unit root test and co-integration are applied initially, whereas the impulse response function reconfirms and captures the estimated results provided by the VAR to predict the relative strength of variables of interest against stocks in other variables.

\subsection{Unit root test}

The secondary data is the basis for the time series analysis, and has constant mean and variance over time. The main problem faced during the analysis of the time series data is the stationarity of data which mainly leads to the dales regression analysis and has high R-squared value, suggesting no significant association between the variables. This mainly results in the bias and spurious findings and conclusions. Thus to overcome the stationarity problem Augmented Dickey Fuller (ADF), ADF GLS and Phillips-Peron unit root tests are applied, which provides the differentiation of considered variables until the stationarity of the variables is

DE GRUYTER OPEN
Timisoara Journal of Economics and Business | ISSN: 2286-0991 | www.tjeb.ro Year 2015 | Volume 8 | Issue 1 | Pages: 103 - 136 
Ahmad, F. (2015).

Determinants of Savings Behavior in Pakistan: Long Term- Short Term Association and Causality

achieved. After the stationarity test and the confirmation of variables stationarity, the cointegration test is applied.

\subsection{Co-integration test}

To examine the long term association between the considered variables, the Johansen and Juselius (J-J) (1990) co-integration test is applied. This approach was developed on the assumption that when two or more non-stationarity series are combined then they result into linear stationary combination, such time series are co-integrated with each other (Engel and Granger, 1987). The linear stationary combination is termed as co-integrating vector and indicates the long run equilibrium between considered variables (Gujarati, 2003). The J-J cointegration test is conducted through VAR model given as follows:

$$
X_{t}=\beta_{1} X_{t-1}+\beta_{2} X_{t-2}+\beta_{3} X_{t-3}+\cdots+\beta_{k} X_{t-k}+\mu+\varepsilon_{t}
$$

where $X_{t}$ is the vector of non-stationary variables integrated of same order, $\mu$ is the vector of intercept, $\beta_{k}$ is a matrix of coefficients, and $\varepsilon_{t}$ is the vector of error term.

In the co-integration test, Trace statistics (TS) and the Maximum Eigen value (ME) statistics are used to determine the number of co-integrating vectors. After getting the ME statistics and TS value, each is compared with its t-statistics value to conclude whether variables are co-integrated or not. If the ME statistics and TS values are greater than their respective $t-$ statistics value then null hypothesis (i.e. co-integration, $r=0$ ) is rejected, indicating that the long term co-integration exists between the variables in the vector. The co-integration tests are sensitive to the proper lag length selection in the VAR model. Various information criteria can be used to select the optimal lag length; current study used Akaike information criterion (AIC), Schwarz information criterion (SC) and Hannan-Quinn information criterion (HQ) for lag length selection.

\subsection{Vector Error Correction Model}

Most of the existing studies have used structural models for macroeconomic variables, where some variables are considered as endogenous and other exogenous variables. The assumption regarding each variable must be specified before the estimation of models. On the other hand, Sims (1980) criticized the view by arguing that this classification of variables is subjective whereas all variables must be considered as endogenous variables. He further concluded that VAR model is better than as compared to working with structural model.

Traditionally, the studies used the log of variables and employ the VAR model models which results in the false and misleading conclusion of the studies. Thus the use of the unit root test becomes necessary to overcome the misleading and spurious results.

DE GRUYTER OPEN
Timisoara Journal of Economics and Business | ISSN: 2286-0991 | www.tjeb.ro Year 2015 | Volume 8 | Issue 1 | Pages: 103 - 136 
Ahmad, F. (2015).

Determinants of Savings Behavior in Pakistan: Long Term- Short Term Association and Causality

If the variable series are not stationary at level then the stationarity test is conducted first differences. If the variable is not stationary at first level then the test is carried out at second difference and so on. If the variables are stationary, simple regression analysis and VAR model is applied, whereas when the variables are stationary at first or second difference and are cointegrated then the Vector Error Correction Model (VECM) is applied. When VECM is reparameterized then it becomes the same as VAR in levels, thus VAR can be used in place of VECM (Ibrahim, 2006). There are several advantages of using a VAR model; first, the low computation and second comprehensive economic interpretation mainly come from the associated Impulse Response Function (IRF). Furthermore, the VECM, IRF suggests that the influence of shocks on variables is permanent whereas in VAR at level IRF allow historical effects to decide whether the shocks are permanent or not (Ibrahim, 2006: and Kassim et al., 2009).

\subsection{Impulse response function}

An IRF measure time profile of each variable response to shocks in itself and in other variables over the period of time. The estimated VAR is used to stimulate the IRF and is innovation in it which may be contemporaneously correlated. This shows that the shock in one variable contemporaneous correlated with the innovation of other variable, thus the shocks to individual variable may not be represented adequately. To solve this issue innovations are orthogonalize by using Cholesky decomposition (Sims, 1980), but this approach was sensitive to the variables ordering. To overcome the ordering in orthogonalized model Pesaran \& Shin (1998) developed IRF.

\subsection{Granger Causality}

Numerous models are used in the literature to predict the association between savings and macroeconomic variables, among them the most commonly used approach is the VAR model. The current study also used the VAR model because it is free from presumptions that are considered in other approaches (Sims, 1980). The VAR model uses applications which increase the possibility of measuring the interrelation between variables (such as Granger causality). The Granger causality is used to determine the unidirectional, bidirectional relationship or independence between variables. This model aims to decide whether the past value of independent variables $(X)$, helps in predicting the value of explanatory variable $\left(Y_{t+1}\right)$, then $\mathrm{X}$ granger causes the $\mathrm{Y}$.

Before testing the granger causality, the integration and co-integration of the time series is checked. The integration is done to check the stationarity of the series through unit root tests. The co-integration of the series is checked through co-integration test. In VAR model degree of freedom is missed because the variables imported are in first difference. Other Another important aspect of the VAR model is that it makes variables to be estimated, thus making the interpretation of co-efficient difficult. As granger causality test is based on the VAR model, so the problem will also occur in the results as well.

\section{DE GRUYTER OPEN}

Timisoara Journal of Economics and Business | ISSN: 2286-0991 | www.tjeb.ro Year 2015 | Volume 8 | Issue 1 | Pages: 103 - 136 
Ahmad, F. (2015).

Determinants of Savings Behavior in Pakistan: Long Term- Short Term Association and Causality

\subsection{Toda Yamamoto technique}

In order to overcome the problems of the VAR model Toda \& Yamamoto (1995) presented a new model Toda Yamamoto model to check the causality without checking for the integration and co-integration. The Toda-Yamamoto causality test is for the series that have arbitrary order of integration and limits all the problems associated with conventional cointegration tests.

There are four steps involved the in Toda Yamamoto test. The first step is to determine the maximum order of integration (represented by $d_{\max }$ ) for the length of all series by using unit root tests. The second step inVol.ves involves the determination of optimal lag in the VAR model (represented by $\mathrm{K}$ ), by using the information criteria such as Akaike Information Criteria. The third step is the estimation of VAR in levels with the modified order of $P=K+d_{\max }$. The last step is applying Wald test for Granger causality.

\section{Results and Findings}

The analysis of the current study started with the selection of eight macroeconomic variables (i.e. GDP per capita, inflation rate, financial development, dependency ratio, exchange rate, industrial production, M2 and fiscal deficit) as determinants of private savings. The private saving variable and eight macroeconomic variables are first converted into log form to overcome the problem of heteroskedasticity.

The unit root tests are conducted to investigate that the data under consideration is stationary or not. For this purpose the current study used the ADF, ADF GLS and PP tests. The results of the three approaches are given in Table 1 . The results indicate that the null hypothesis at level for most of the variables cannot be rejected. On the other hand, all variables are negative compared to the critical values of $1 \%$, in first differences, therefore the null hypothesis is rejected in levels for all variables. The considered three unit root tests provide the same results in levels and first difference. Thus, it can be concluded that all variables are integrated of the first order (are I(1)). As a whole, the results predict that long term association can exist between the considered variables. 
Ahmad, F. (2015).

Determinants of Savings Behavior in Pakistan: Long Term- Short Term Association and Causality

Table 1. Unit Root Tests Results

\begin{tabular}{|c|c|c|c|c|}
\hline \multicolumn{5}{|l|}{ Augmented Dickey Fuller } \\
\hline & & With Intercept & \multicolumn{2}{|c|}{ With Trend and Intercept } \\
\hline Variables & Level & First Difference & Level & First Difference \\
\hline Private savings & -1.66 & $-6.23 *$ & -4.21 & $-6.47 *$ \\
\hline GDP per capita & -0.61 & $-4.72 *$ & -2.71 & $-4.64 *$ \\
\hline Inflation rate & $-3.32 * *$ & $-7.50 *$ & $-3.31 * * *$ & $-7.45 *$ \\
\hline Financial development & $-3.25 * *$ & $-4.57 *$ & -2.54 & $-4.59 *$ \\
\hline Dependency ratio & $-3.21 * *$ & 0.28 & -1.05 & $-3.06 *$ \\
\hline Exchange rate & 0.40 & $-4.75 *$ & -1.90 & $-4.83 *$ \\
\hline Industrial Production & -0.51 & $-5.26 *$ & -3.00 & $-5.18 *$ \\
\hline M2 & -0.62 & $-5.08 *$ & -3.10 & $-5.05 *$ \\
\hline Fiscal Balance & 1.07 & $-6.53 *$ & -1.88 & $-6.81 *$ \\
\hline \multicolumn{5}{|l|}{ Dickey Fuller-GLS } \\
\hline & & With Intercept & \multicolumn{2}{|c|}{ With Trend and Intercept } \\
\hline Variables & Level & First Difference & Level & First Difference \\
\hline Private savings & -1.66 & $-6.09 *$ & -0.79 & $-6.20 *$ \\
\hline GDP per capita & 1.86 & $-3.96 *$ & -1.80 & $-4.49 *$ \\
\hline Inflation rate & $-3.17 *$ & -0.82 & $-2.93 * * *$ & $-4.81 *$ \\
\hline Financial development & $-2.36 * *$ & $-4.11 *$ & -2.62 & $-4.53 *$ \\
\hline Dependency ratio & $-2.93 *$ & -0.23 & $-3.13 * *$ & -1.02 \\
\hline Exchange rate & 1.12 & $-3.83 *$ & -1.59 & $-4.45 *$ \\
\hline Industrial Production & 1.51 & $-4.56 *$ & -2.14 & $-5.07 *$ \\
\hline M2 & 0.58 & $-5.13 *$ & $-3.12 * * *$ & $-5.15 *$ \\
\hline Fiscal Balance & 1.95 & $-6.46 *$ & -1.92 & $-6.97 *$ \\
\hline \multicolumn{5}{|l|}{ Phillips-Peron } \\
\hline & & With Intercept & \multicolumn{2}{|c|}{ With Trend and Intercept } \\
\hline Variables & Level & First Difference & Level & First Difference \\
\hline Private savings & -2.14 & $-6.21 *$ & -0.39 & $-7.14 *$ \\
\hline GDP per capita & -0.56 & $-4.69 *$ & -2.95 & $-4.61 *$ \\
\hline Inflation rate & $-2.99 * *$ & $-7.58 *$ & $-3.16 *$ & $-7.74 *$ \\
\hline Financial development & -2.23 & $-4.57 *$ & -2.17 & $-4.54 *$ \\
\hline Dependency ratio & -1.47 & -1.41 & -0.63 & -1.95 \\
\hline Exchange rate & 0.23 & $-4.80 *$ & -2.07 & $-4.87 *$ \\
\hline Industrial Production & -0.51 & $-5.29 *$ & -3.00 & $-5.17 *$ \\
\hline M2 & -0.68 & $-4.97 *$ & -2.51 & $-4.96 *$ \\
\hline Fiscal Balance & 1.28 & $-6.53 *$ & -2.01 & $-6.82 *$ \\
\hline
\end{tabular}

Where $* 1 \%, * \star 5 \%$ and $* * \star 10 \%$ level of significance

Source: Author's calculations.

DE GRUYTER OPEN
Timisoara Journal of Economics and Business | ISSN: 2286-0991 | www.tjeb.ro Year 2015 | Volume 8 | Issue 1 | Pages: 103 - 136 
Ahmad, F. (2015).

Determinants of Savings Behavior in Pakistan: Long Term- Short Term Association and Causality

In order to investigate the long run association among the variables the Johansen-Juselius co-integration test was used. Before testing for the long run association, the optimal lag length was determined, because of the sensitivity of the co-integration towards the lag structure of the VAR model. Thus, the first VAR model is applied on the variables and then the information criteria was used to get the optimal lag length. The current study used AIC, $\mathrm{SC}$ and $\mathrm{HQ}$ to get the optimal lag length. The results of the optimal lag selection information criterion are given in Table 2. From the results it can be concluded that the optimal lag length for the co-integration is 3 .

Table 2. Optimal lag length selection tests results

\begin{tabular}{cccc}
\hline Lags & $\begin{array}{c}\text { Akaike information } \\
\text { criterion }\end{array}$ & $\begin{array}{c}\text { Schwarz information } \\
\text { criterion }\end{array}$ & $\begin{array}{c}\text { Hannan-Quinn } \\
\text { information criterion }\end{array}$ \\
\hline $\mathbf{1}$ & -28.42 & -24.54 & -27.04 \\
$\mathbf{2}$ & -31.42 & -24.05 & -28.80 \\
$\mathbf{3}$ & $-38.65^{*}$ & $-27.79^{*}$ & $-34.78^{*}$ \\
\hline
\end{tabular}

* indicates lag order selected by the criterion

Source: Author's calculations.

The optimal lag length is used to conduct the Johansen-Juselius co-integration test at the lag level of 3; the results are presented in table 3. In identifying the number of co-integration among variables TS and MS are used. The TS and MS suggest the presence of 9 unique co-integrating vectors among the selected variables at the significance level of $5 \%$. The results are persistent both according to TS and to MS value test. From the Johansen-Juselius co-integration test it can be concluded that the long run association exits between the variables and at least one sided causality exists between the considered variables.

Table 3. Co-integration Test Results

\begin{tabular}{cccccc}
\hline $\begin{array}{c}\text { No. of } \\
\text { Co-integrations }\end{array}$ & Eigen value & Trace Statistic & Probability & $\begin{array}{c}\text { Max-Eigen } \\
\text { Statistic }\end{array}$ & Probability \\
\hline None * & 0.97 & 482.39 & 0.0000 & 128.68 & 0.0000 \\
At most 1 * & 0.96 & 353.72 & 0.0000 & 123.71 & 0.0000 \\
At most 2 * & 0.91 & 230.00 & 0.0000 & 92.34 & 0.0000 \\
At most 3 * & 0.63 & 137.66 & 0.0000 & 37.81 & 0.0362 \\
At most 4 * & 0.61 & 99.85 & 0.0000 & 36.00 & 0.0091 \\
At most 5 * & 0.51 & 63.85 & 0.0001 & 27.00 & 0.0201 \\
At most 6 * & 0.43 & 36.85 & 0.0008 & 21.58 & 0.0128 \\
At most 7 * & 0.21 & 15.26 & 0.0156 & 8.79 & 0.1299 \\
At most 8 * & 0.16 & 6.47 & 0.0130 & 6.47 & 0.0130 \\
\hline
\end{tabular}

Trace test indicates 9 co-integrating equations at the 5\% significance level. * denotes rejection of the hypothesis at the $5 \%$ confidence level.

Source: Author's calculations.

DE GRUYTER OPEN
Timisoara Journal of Economics and Business | ISSN: 2286-0991 | www.tjeb.ro Year 2015 | Volume 8 | Issue 1 | Pages: 103 - 136 
Ahmad, F. (2015).

Determinants of Savings Behavior in Pakistan: Long Term- Short Term Association and Causality

Table 4. First normalized long run co integration equation: dependent variable private savings

\begin{tabular}{cccc}
\hline & Coefficient & Standard error & t-Statistics \\
\hline GDP per capita & 12.52 & 1.40 & 8.98 \\
Inflation rate & 0.15 & 0.09 & 1.60 \\
Financial development & 10.90 & 0.86 & 12.70 \\
Dependency ratio & 74.39 & 7.11 & 10.46 \\
Exchange rate & 0.54 & 0.25 & 2.16 \\
Industrial Production & 5.32 & 0.53 & 9.96 \\
M2 & -16.53 & 0.97 & -17.11 \\
Fiscal Balance & 0.71 & 0.17 & 4.22 \\
\hline
\end{tabular}

Source: Author's calculations.

The first normalized equation is summarized in Table 4 and provides the long run association between savings and explanatory variables. The common rule relating the significance of relationship is that when coefficient is double the value of standard error than the relationship is significant. Thus the first normalized equation suggests six significant positive long run associations of GDP per capita, financial development, dependency ratio, exchange rate, industrial production and fiscal deficit with private savings and one negative significant associations of M2 with savings. Whereas inflation has insignificant association with savings.

The significant positive association of GDP per capita with private savings suggests that with the growth in the economic activities the earnings of the individual increases. The income of the individual is greater than the consumption, thus the remaining income is saved (absolute income hypothesis). There is also a precautionary motive in the savings by the individual in long run; they want to secure against any uncertain economic event (precautionary savings hypothesis). The significant positive association of financial development with private savings suggests that loans to private sector stimulate the savings behavior to service the interest and debt payments due in future. The growth in financial development stimulates the flow of funds, the efficient allocation of resources and increases the economic activities in the country, resulting in the income growth and savings.

With the increase in old people as compared to young people (dependency ratio) stimulate the growth in savings to ensure the future consumption (precautionary savings hypothesis). Furthermore old people face uncertainty when it comes to relating the future jobs and earnings (buffer stock theory). Thus, in order to secure against future uncertainty, savings rate of old age people should increase. The positive association of industrial production with savings suggests that in long run with the growth in industrial production the income of the individual increases. Because of the uncertainty associated with the job, future 
Ahmad, F. (2015).

Determinants of Savings Behavior in Pakistan: Long Term- Short Term Association and Causality

consumption and income individual saves residual income to ensure future stable consumption (precautionary savings hypothesis and buffer stock theory).

The depreciation in local currency stimulates the savings behavior. Pakistan is a developing economy and is mostly dependent on the imports, thus an increase in the exchange rate increases the import bill and losses (precautionary savings hypothesis). The expectation of the increase in exchange rate induces the private investor to save more to secure against losses. Similarly, with the increase in fiscal deficit, private savings increases, because of the expected increase in tax rate by the government to cover the fiscal deficit.

The significant negative relation between $\mathrm{M} 2$ and savings suggest that in long run with the increase in money supply in the economy the interest rate declines. The funds are easily available at low rate in the market for future use, therefore individuals prefer to consume the current earnings with the intent that they will get the funds at lower rates.

\subsection{VECM results}

The results given in Table 3 conclude that there exists long term association between all the variables in the long run. In order to investigate the short term dynamics between variables and the impact of each explanatory variable on private savings VECM was applied. The statistical significance and size of the Error Correction Term (ECT) measures the extent and tendency of each explanatory variable to return back to its long run equilibrium position. The endogenous variables in the analysis are lagged explanatory variables and one lagged ECT and R-squared provides their joint significance. If the coefficient value is significant for the lagged explanatory variables, then it suggests that the importance of explanatory variables in predicting private savings current movement and adjustment towards previous equilibrium error term.

The ECT1, ECT2, ECT3, ECT4, ECT5, ECT6, ECT7 and ECT8 represents short term ability of GDP per capita income, inflation rate, financial development, dependency ratio, exchange rate, industrial production, M2 and fiscal deficit to return there long run equilibrium position. The results provide significant ability of the four variables to return their long run equilibrium position by providing significant negative coefficient value of ECT8 and significant positive coefficient value for ECT2, ECT4 and ECT5.

In VECM lagged co-efficient of explanatory variables captures the short run effects on the dependent variable (Engle and Granger, 1987). The results indicate that all variables have different impact on the dependent variable. 
Ahmad, F. (2015).

Determinants of Savings Behavior in Pakistan: Long Term- Short Term Association and Causality

The results in Table 5 provide the significant short term negative coefficient value for both lagged variables of the GDP per capita income, suggesting that per capita income has significant short term influence in explaining changes in the savings rate. The coefficient values for deposit rate as given by Table 5 are -7.19 and -6.26 , suggesting that in short run $1 \%$ raise in the per capita income result in the $7.19 \%$ and $6.26 \%$ decline in the private savings. Similarly the lagged variable of financial development has significant negative short term influence with coefficient value of -2.42 suggesting that $1 \%$ raise in financial development brings $2.41 \%$ decline in savings rate. It can be concluded for the results in Table 5 that only the GDP per capita and financial development have a short term influence on the private savings rate. Inflation rate, dependency ratio, exchange rate, industrial production, $\mathrm{M} 2$ and fiscal deficit have no short run impact on the savings behavior.

Table 5. Vector Error Correction Model Results

\begin{tabular}{|c|c|c|c|c|}
\hline & Coefficient & Standard Error & t-Statistics & Probability \\
\hline d_private savings_1 & -0.81 & 0.64 & -1.26 & 0.23 \\
\hline d_private savings_2 & -0.64 & 0.42 & -1.54 & 0.15 \\
\hline d_GDP per capita_1 & -7.19 & 3.55 & -2.03 & 0.07 \\
\hline d_ GDP per capita_2 & -6.26 & 2.81 & -2.23 & 0.05 \\
\hline d_ inflation rate_1 & -0.21 & 0.18 & -1.16 & 0.27 \\
\hline$d_{-}$inflation rate _2 & -0.07 & 0.12 & -0.58 & 0.57 \\
\hline d_financial development_1 & -3.56 & 2.12 & -1.66 & 0.12 \\
\hline d_financial development_2 & -2.42 & 1.31 & -1.84 & 0.09 \\
\hline d_dependency ratio_1 & 80.15 & 160.05 & 0.50 & 0.63 \\
\hline d_dependency ratio_2 & -237.99 & 203.39 & -1.17 & 0.26 \\
\hline d_exchange rate_1 & 0.10 & 1.09 & 0.09 & 0.93 \\
\hline d_exchange rate_2 & -0.98 & 0.93 & -1.06 & 0.31 \\
\hline d_ industrial production_1 & 0.15 & 1.34 & 0.11 & 0.91 \\
\hline$d_{-}$industrial production_2 & 1.41 & 1.11 & 1.27 & 0.23 \\
\hline d_M2_1 & 5.40 & 3.04 & 1.78 & 0.10 \\
\hline d_M2_2 & 2.66 & 2.134 & 1.25 & 0.24 \\
\hline d_ fiscal deficit_1 & 0.87 & 0.65 & 1.35 & 0.20 \\
\hline$d_{\text {_ fiscal deficit_2 }}$ & 0.47 & 0.38 & 1.24 & 0.24 \\
\hline EC1 & 0.38 & 0.82 & 0.47 & 0.65 \\
\hline EC2 & 7.83 & 4.05 & 1.93 & 0.08 \\
\hline EC3 & 0.45 & 0.26 & 1.72 & 0.11 \\
\hline EC4 & 6.71 & 3.37 & 1.99 & 0.07 \\
\hline EC5 & 41.69 & 20.01 & 2.08 & 0.06 \\
\hline EC6 & 0.26 & 1.45 & 0.18 & 0.86 \\
\hline EC7 & 0.73 & 2.00 & 0.37 & 0.72 \\
\hline EC8 & -7.90 & 4.09 & -1.93 & 0.08 \\
\hline $\begin{array}{c}\text { R-squared } \\
\text { Adjusted R-squared }\end{array}$ & $\begin{array}{l}0.83 \\
0.49\end{array}$ & & & \\
\hline
\end{tabular}

Source: Author's calculations.

DE GRUYTER OPEN
Timisoara Journal of Economics and Business | ISSN: 2286-0991 | www.tjeb.ro Year 2015 | Volume 8 | Issue 1 | Pages: 103 - 136 
Ahmad, F. (2015).

Determinants of Savings Behavior in Pakistan: Long Term- Short Term Association and Causality

The ECT2 significant positive coefficient value suggesting that inflation rate has the tendency to correct its previous period disequilibrium with the rate of $7.83 \%$ annually.

The estimated coefficient value of ECT4 suggests a $6.71 \%$ annual speed of adjustment in savings towards long run equilibrium given an initial $1 \%$ change in the dependency ratio. It can be concluded that with the increase in age, savings rate adjust itself towards the equilibrium by increase in savings trend by old age people. Thus with the increase in the number of old age people, the savings rate also increases in order to safeguard the future consumption and from protect against income uncertainty.

The significant but positive coefficient value of ECT5 suggests that the exchange rate has short term ability of returning to its equilibrium position with $41.69 \%$ recovery annually. The ECT8 has a significant negative coefficient value suggesting that the fiscal deficit has the significant ability to correct the previous period disequilibrium with the rate of $7.90 \%$ annually. This suggests that with the increase in fiscal deficit the individual saves more in the next year to maintain the savings rate because the government increases taxes to cover up budgetary deficits.

The residuals of the model was checked for the existence of serial correlation, heteroskedasticity and normal distribution. The current study used the Ljung-Box $Q$ test to check for the serial correlation in the residuals of the model, the results of the test are given in Table 6.

Table 6. Vector Error Correction Model Results

\begin{tabular}{ccc}
\hline Test & Statistic & Probability \\
\hline Ljung-Box Q & 10.19 & 0.11 \\
\hline
\end{tabular}

Source: Author's calculations.

In the correlation test the Ljung-Box $\mathrm{Q}$ value and its probability is used to either accept or reject the null hypothesis of existence of no correlation in the residual of the model. The results in Table 6 accepts the null hypothesis because the p-value is greater than $5 \%$, suggesting that there is no correlation in the residual of the model, which is desirable for a good model.

Table 7. Heteroskedasticity test

\begin{tabular}{ccc}
\hline Test & Statistic & Probability \\
\hline LM Chi-square & 1.33896 & 0.719904 \\
\hline
\end{tabular}

Source: Author's calculations.

DE GRUYTER OPEN 
Ahmad, F. (2015).

Determinants of Savings Behavior in Pakistan: Long Term- Short Term Association and Causality

The heteroskedasticity of the residual was checked by using ARCH test. In this test LM Chisquare value and its probability is used to either accept or reject the null hypothesis of no ARCH effect or existence of homoskedasticity. The results in Table 7 accepts the null hypothesis because the p-value is greater than $5 \%$, suggesting that there is no heteroskedasticity in the residual and residuals are homoskedasticity, which is desirable for a good model.

Table 8. Normality test

\begin{tabular}{ccc}
\hline Test & Statistic & Probability \\
\hline Doornik-Hansen test (Chi-square) & 14.0754 & 0.7242 \\
\hline
\end{tabular}

Source: Author's calculations.

At the end residuals are checked whether they are normally distributed or not. For this purpose Doornik-Hansen test with its Chi-square is normally used with its p-value to either accept or reject the null hypothesis of existence of normal distribution. The Chi-square and its $\mathrm{p}$-value are given in Table 8. The results suggest that the $\mathrm{p}$-value of Chi-square is greater than $5 \%$ thus the null hypothesis is accepted, suggesting that residuals are normally distributed.

\subsection{Impulse response functions}

The Toda \& Yamamoto (1995) approach is used to estimate the long run Granger causality among the variables, whereas it does not provide evidence on each variable's response to the innovation in other variable, and whether shocks are permanent or not. This can be done by using impulse response analysis as suggested by Pesaran \& Shin (1998).The impulse response function results are given in the figures below. The results were estimated for a 10 years' time horizon in order to check the persistence of stock during the long run. The impulse response plots are given with zero line, generally, when responses are below the zero line then responses are statistically insignificant whereas when responses are above the zero line then responses are statistically significant.

The generalized responses of savings to the shocks in explanatory variables are given in next figures. It can be seen in Figures 1 to 8 that savings responds immediately to the shocks in all explanatory variables. Furthermore savings respond positively to the shocks in inflation rate, dependency ratio, industrial production and fiscal deficit, whereas savings respond negatively to the GDP per capita income, financial development, exchange rate and M2.

Shocks in the GDP per capita have negative impact on the savings rate, at the start the magnitude of response of savings is negative and reaches the lowest level at the end of year 3 , afterwards the savings level remains in the negative trend and moves towards the positive region at the end of year 10 . This suggests that the shocks in the GDP has negative influence on the savings level, with the increase in economic activities income level of individuals in

DE GRUYTER OPEN
Timisoara Journal of Economics and Business | ISSN: 2286-0991 | www.tjeb.ro Year 2015 | Volume 8 | Issue 1 | Pages: 103 - 136 
Ahmad, F. (2015).

Determinants of Savings Behavior in Pakistan: Long Term- Short Term Association and Causality

economy declines resulting in the consumption of whole income. The savings decreases because of the consistent increase in the GDP per capita and security that the individual will be having stable earnings in the future.

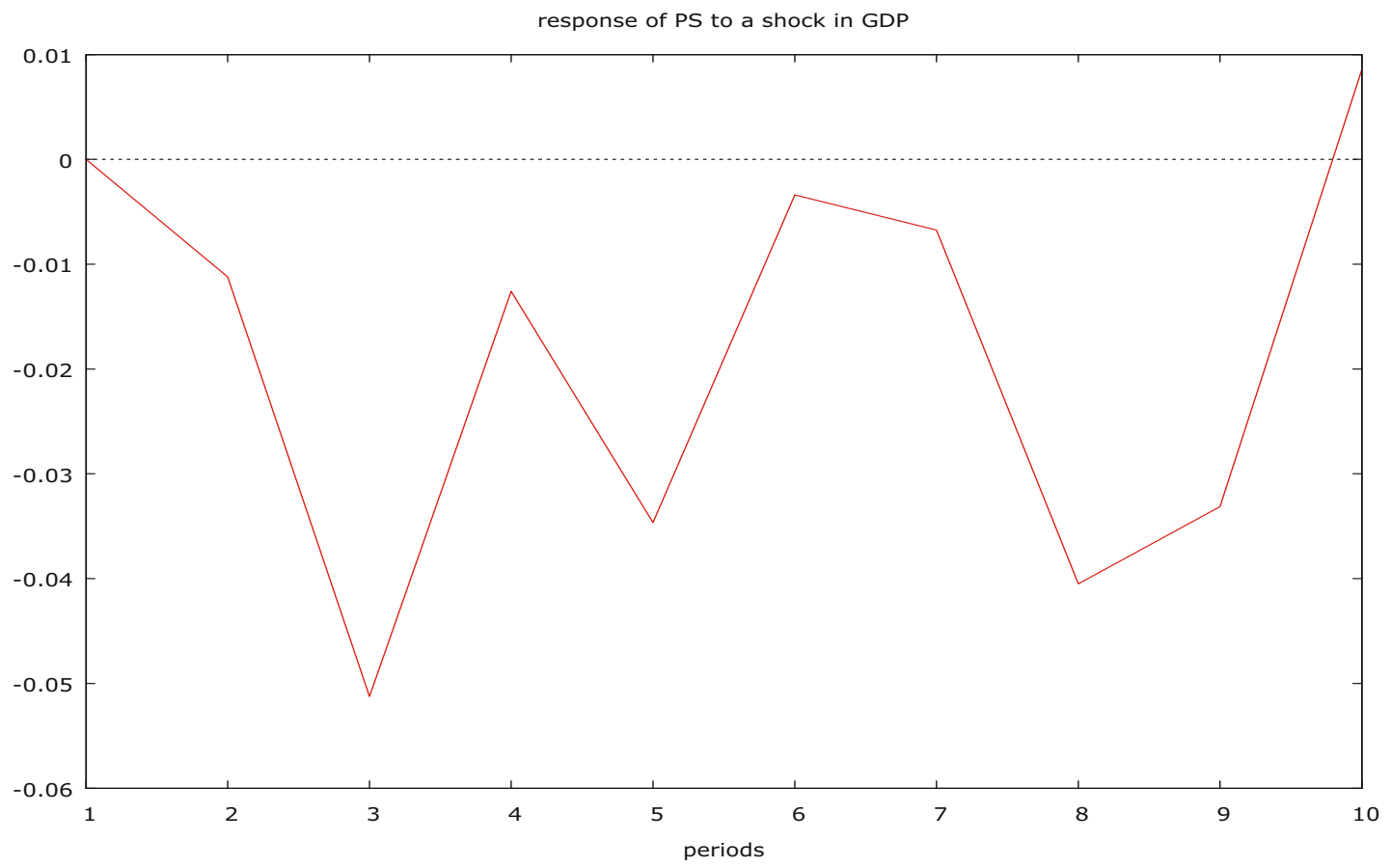

Figure 1. Responses of savings to GDP per capita

Source: Own preparation.

The Figure 2 shows that savings has mixed response against the inflation rate. In the first year savings respond positively but starts to decline at the start of second year and reaches to lowest level at the end of third year. In between fourth and ninth year savings respond both positively and negatively and reaches the highest level at the end of the tenth year. This suggests that initially with the shocks in inflation rate the individuals do not adjust their savings amount by saving more to maintain the savings level, thus leading to the decline in savings. After 5 years the individuals starts to adjust their savings to maintain a specific level of savings leading to the growth in savings.

The Figure 3 suggest that financial development has negative impact on the savings rate. With the shocks in the financial development the savings rate decline consistently after three years. The increase in financial development provides surety security to the individual that if there their future consumption exceeds the income than they will be having option of loan to meet their future consumption. Therefore, the savings rate consistently declines with the shocks in financial development.

DE GRUYTER OPEN
Timisoara Journal of Economics and Business | ISSN: 2286-0991 | www.tjeb.ro Year 2015 | Volume 8 | Issue 1 | Pages: 103 - 136 
Ahmad, F. (2015).

Determinants of Savings Behavior in Pakistan: Long Term- Short Term Association and Causality

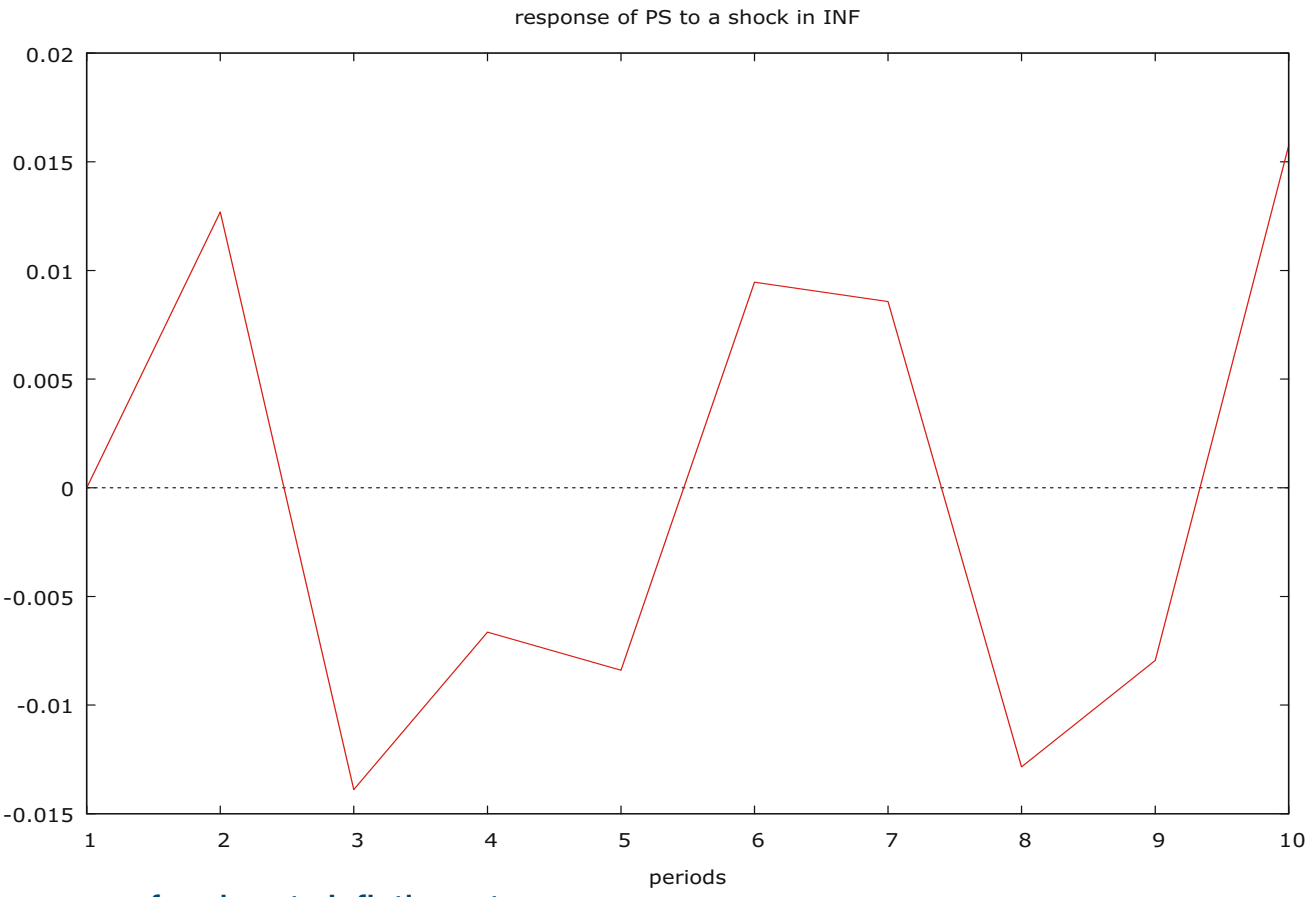

Figure 2. Responses of savings to Inflation rate Source: Own preparation.

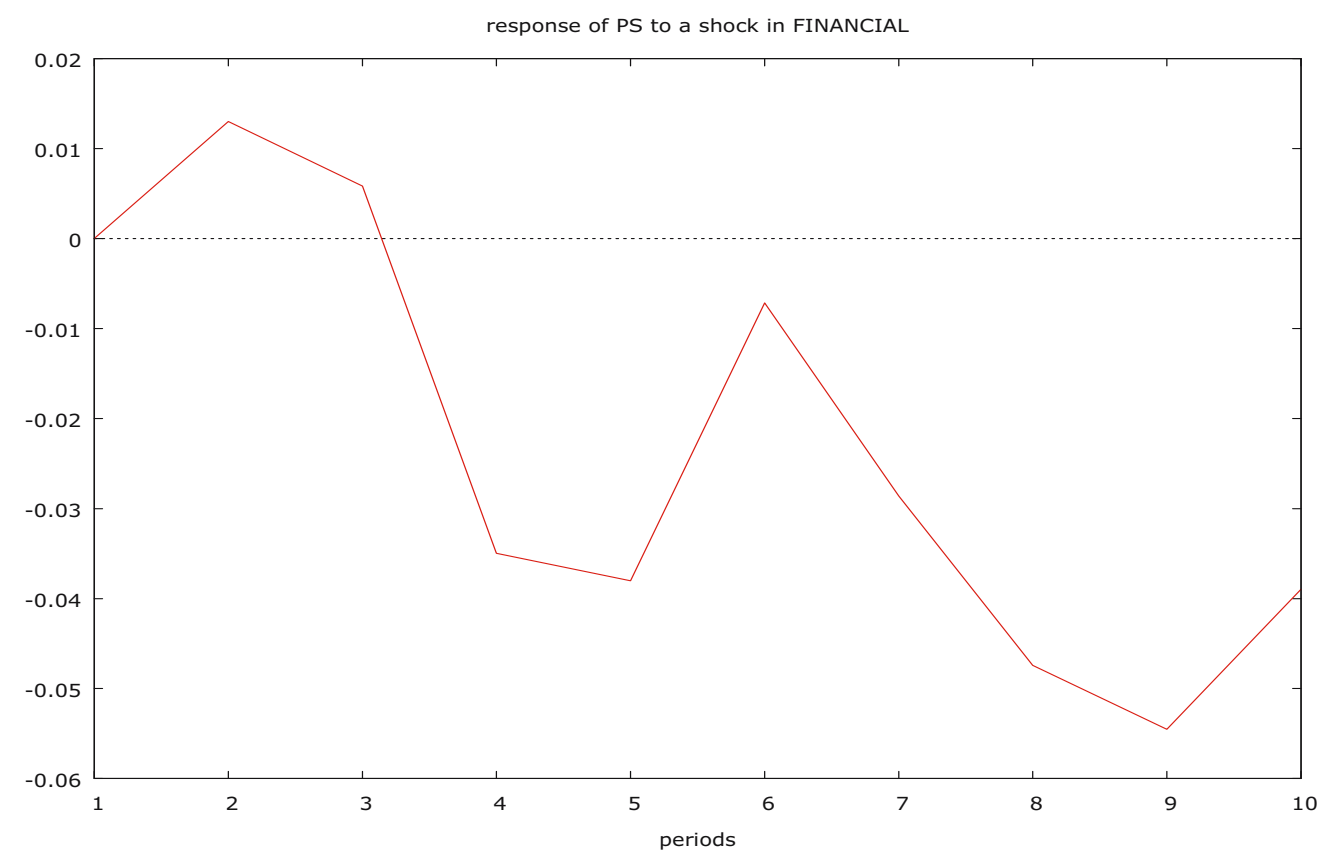

Figure 3. Responses of savings to financial development Source: Own preparation.

DE GRUYTER OPEN 
Ahmad, F. (2015).

Determinants of Savings Behavior in Pakistan: Long Term- Short Term Association and Causality

The Figure 4 suggest that after three years' shocks in the dependency ratio leads to the consistent growth in the savings rate. At the start the individuals are not much concerned with the future consumption but as their age increases they start showing future consumption concern by saving more to secure future consumption.

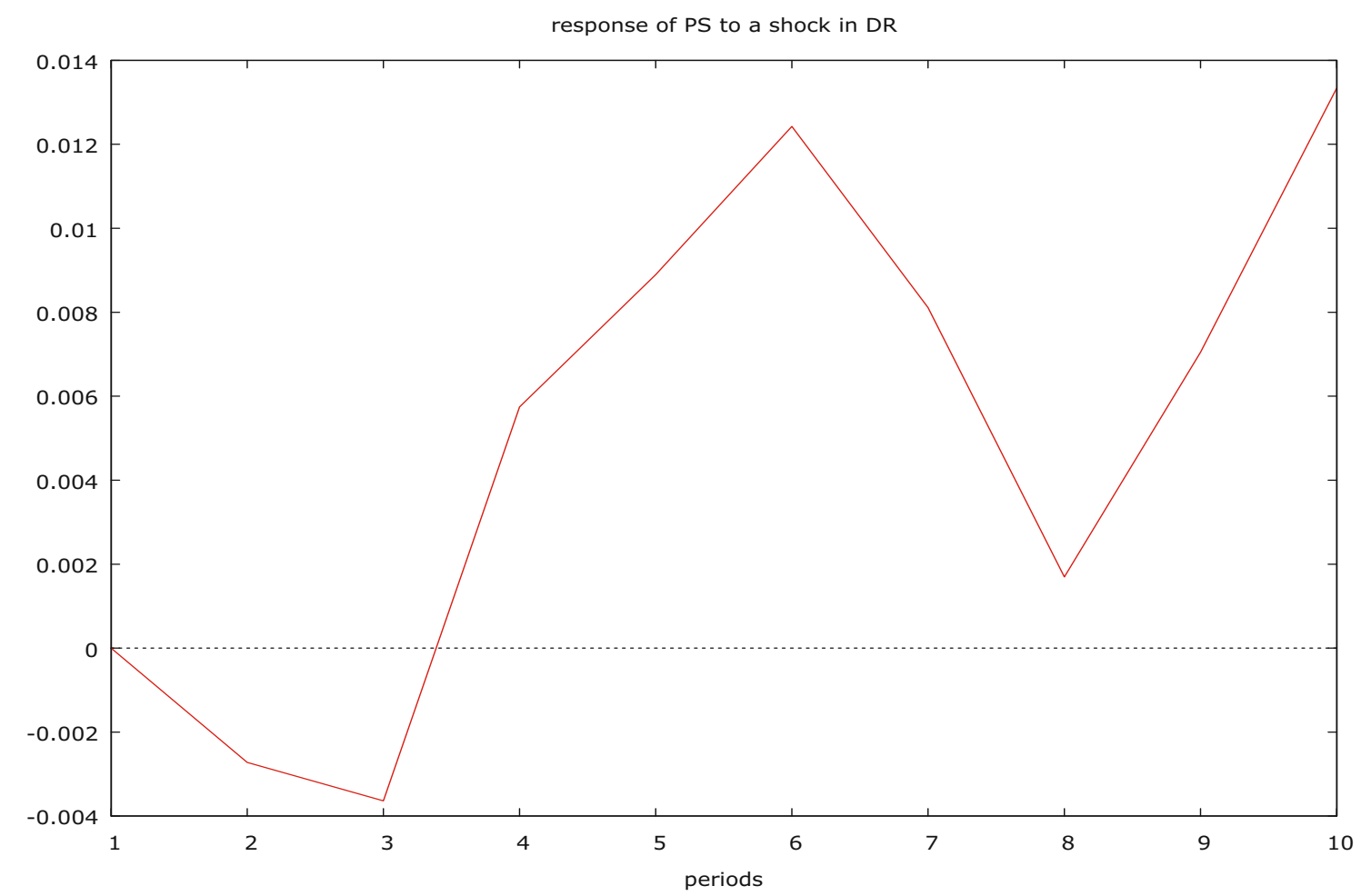

Figure 4. Responses of savings to dependency ratio Source: Own preparation.

The savings rate has a mixed response to the shocks in exchange rate. The Figure 5 suggests that at start savings respond positively to maintain the level of the savings amount by saving more. After three years the savings declines to negative level and increases between year five and seven and then declines and reaches the lowest level at the end of the ninth year. This trend suggests that at start the individual increases the savings to maintain the original purchasing value of savings but with the currency depreciation the purchasing power of the savings amount leads to the decline in savings. 
Ahmad, F. (2015).

Determinants of Savings Behavior in Pakistan: Long Term- Short Term Association and Causality

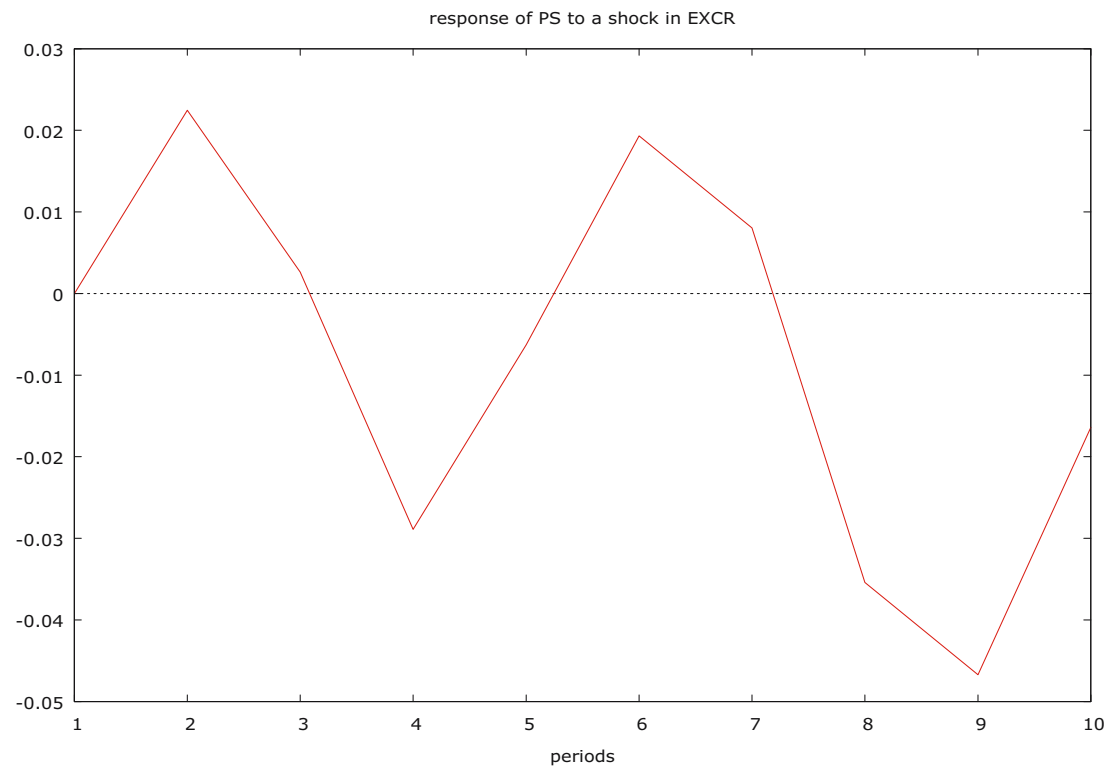

Figure 5. Responses of savings to exchange rate

Source: Own preparation.

The Figure 6 suggests that savings respond positively to the shocks in the industrial production, reaches to the highest level in ninth year. This suggests that the savings level increases because individuals have more earnings than consumption. Thus the individuals save the surplus income. With time the industrial activities increases and the income of the individual, resulting in the surplus income and more savings.

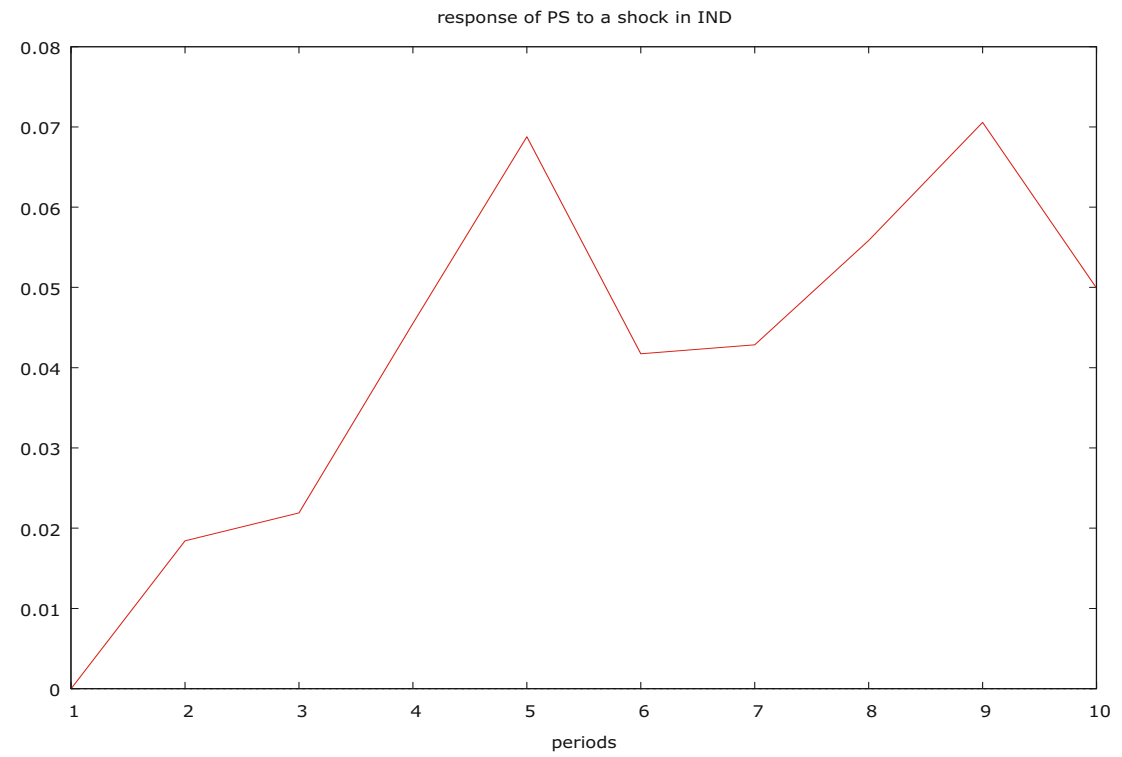

Figure 6. Responses of savings to industrial production Source: Own preparation.

DE GRUYTER OPEN
Timisoara Journal of Economics and Business | ISSN: 2286-0991 | www.tjeb.ro

Year 2015 | Volume 8 | Issue 1 | Pages: 103 - 136 
Ahmad, F. (2015).

Determinants of Savings Behavior in Pakistan: Long Term- Short Term Association and Causality

The Figure 7 suggests that savings respond negatively to the shocks in the M2, because of the excess funds in the economy are saved by the individuals but with the timely availability of funds in the economy, make the individual consume more and save less. As the shocks persists for longer time the uncertainty of the economy converts into the certainty of future availability of less costly funds.

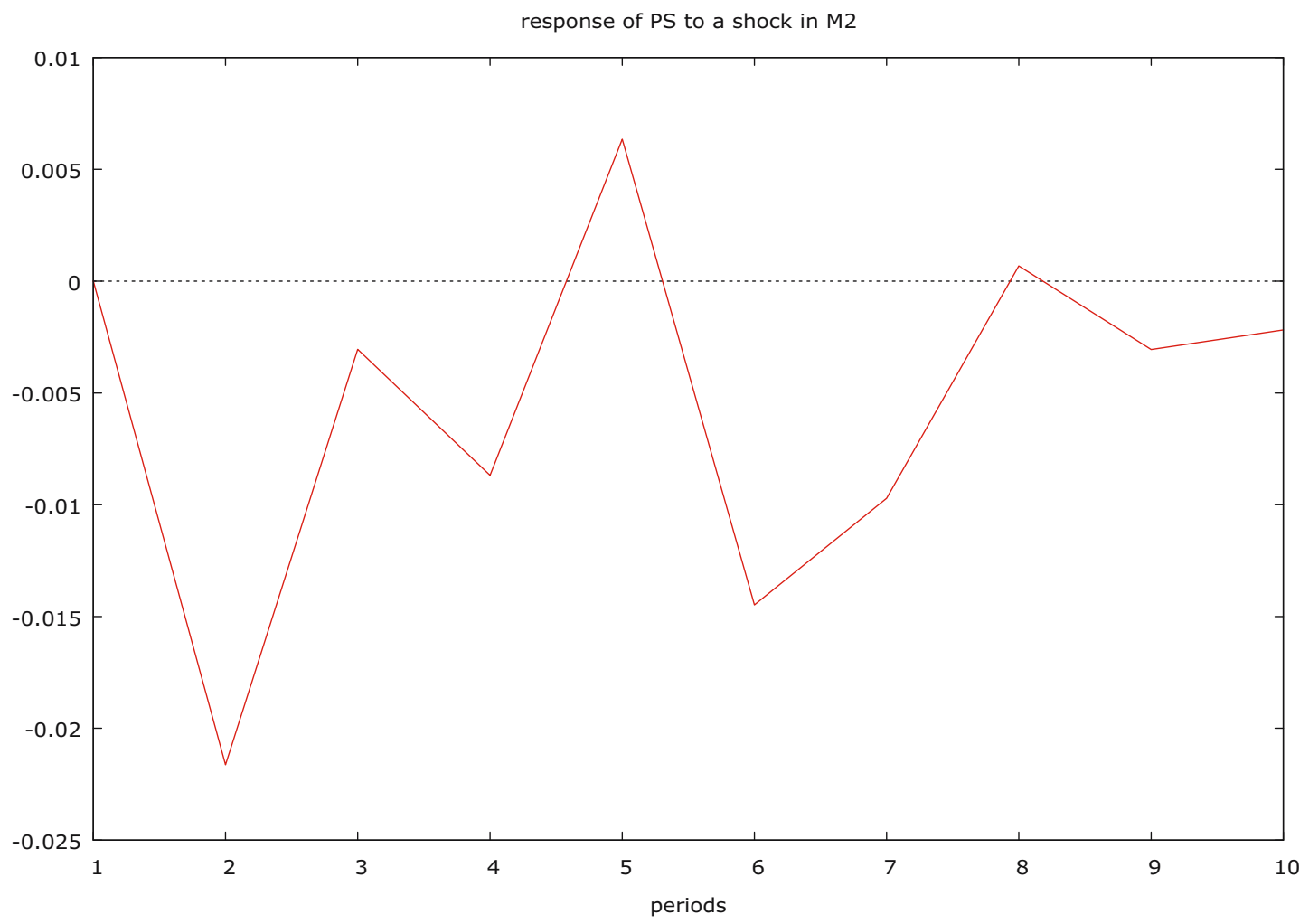

Figure 7. Responses of savings to M2

Source: Own preparation.

The savings respond positively to the shocks in fiscal deficit, initially the savings rate increases in response to shocks in the fiscal deficit but after two years it starts to decline. This suggests that as the fiscal deficit increases individuals initially save more to pay high rates of tax and maintain the certain level of savings later on. 
Ahmad, F. (2015).

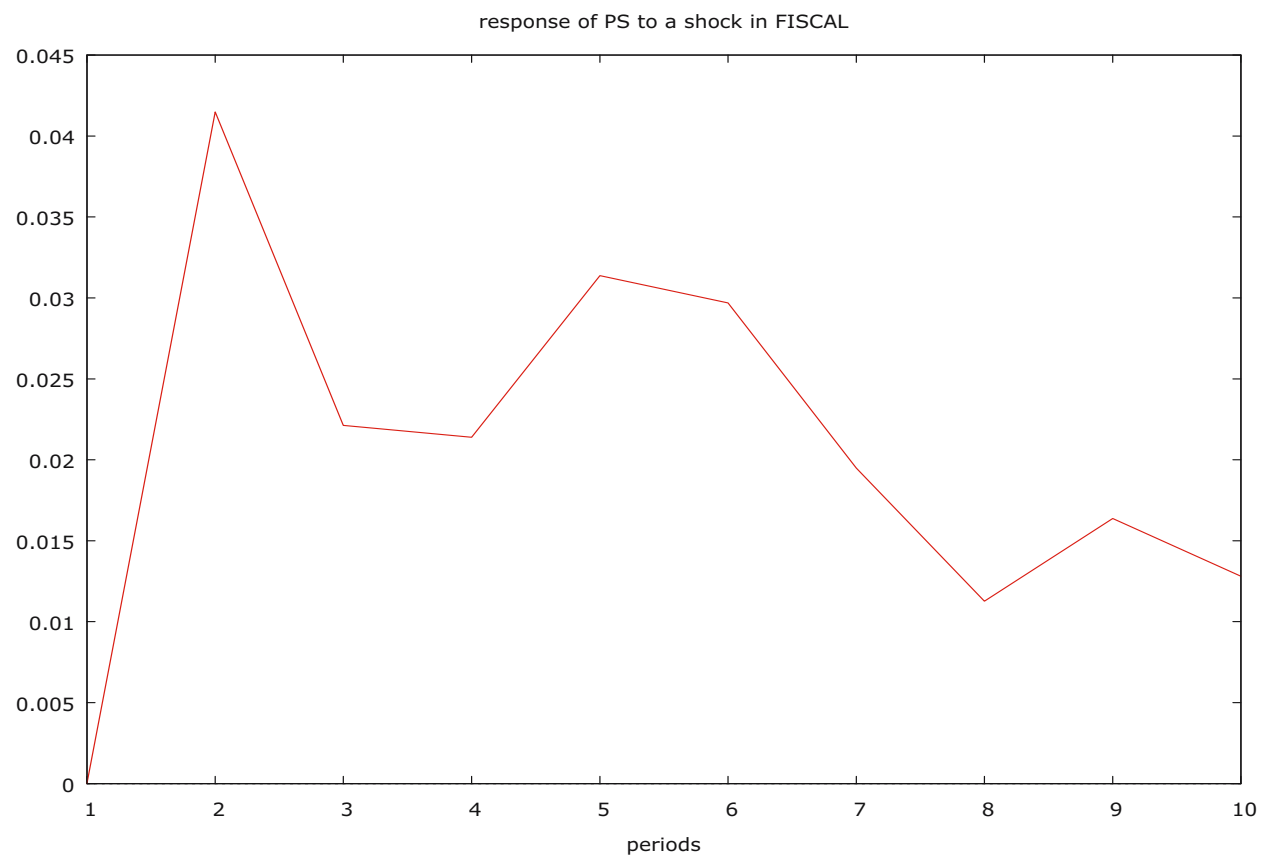

Figure 8. Responses of savings to fiscal deficit

Source: Own preparation

\subsection{Granger Causality test}

In order to confirm the short run association as given by VECM between savings and the explanatory variables, the Granger Causality test was used. In time series analysis the most common approach used to investigate the direction of causality between variables in the short run is the Granger Causality. The results provided by VECM suggest that GDP per capita income and financial development have significant impact on the savings in Pakistan, whereas all other considered explanatory variables do not significantly Granger causes savings rate.

Engle and Granger (1987) suggested that in VECM lagged first co-efficient of explanatory variables capture the short run effects on the dependent variable, therefore it can be concluded that in the short run GDP per capita and financial development influenced the savings level in Pakistan. Whereas the Granger Causality results given in Table 9 suggest that two null hypothesis i.e. "Financial development does not Granger Cause private savings", and "Dependency ratio does not Granger Cause private savings" are rejected, suggesting that in the short run financial development and dependency ratio granger causes changes in the savings level. The VECM and Granger Causality test provides one different variable for the short term association with savings thus it can be concluded form GDP per capita, financial development and dependency ratio has short run impact on the savings. This suggests that in the short run

\section{DE GRUYTER}

\section{OPEN}


Ahmad, F. (2015).

Determinants of Savings Behavior in Pakistan: Long Term- Short Term Association and Causality

GDP per capita, financial development and dependency ratio have impact in changing the level of private savings in Pakistan, whereas remaining explanatory variables has no short run impact on private savings.

Table 9. Granger Causality test

\begin{tabular}{ccc}
\hline Null Hypothesis: & F-Statistic & Probability \\
\hline GDP per capita does not Granger Cause Private savings & 1.44 & 0.2503 \\
Private savings does not Granger Cause GDP per capita & 1.23 & 0.3142 \\
Inflation rate does not Granger Cause Private savings & 0.85 & 0.4791 \\
Private savings does not Granger Cause Inflation rate & 0.21 & 0.8882 \\
Financial development does not Granger Cause Private savings & 2.26 & 0.1000 \\
Private savings does not Granger Cause Financial development & 1.11 & 0.3619 \\
Dependency ratio does not Granger Cause Private savings & 2.90 & 0.0508 \\
Private savings does not Granger Cause Dependency ratio & 4.12 & 0.0144 \\
Exchange rate does not Granger Cause Private savings & 0.37 & 0.7724 \\
Private savings does not Granger Cause Exchange rate & 2.68 & 0.0639 \\
Industrial production does not Granger Cause Private savings & 0.75 & 0.5333 \\
Private savings does not Granger Cause Industrial production & 0.99 & 0.4102 \\
M2 does not Granger Cause Private savings & 1.50 & 0.2344 \\
Private savings does not Granger Cause M2 & 1.26 & 0.3047 \\
Fiscal deficit does not Granger Cause Private savings & 0.37 & 0.7762 \\
Private savings does not Granger Cause Fiscal deficit & 0.40 & 0.7569 \\
\hline
\end{tabular}

Source: Author's calculations.

\subsection{Toda Yammoto technique}

The Granger causality approach is used to investigate the causality existence and direction of causality between variables, whereas the TY procedure provides long run Granger causality without conducting the co-integration test and estimating the co-integration equation. The TY approach starts with estimating the maximum order of integration by using stationarity tests. As discussed above, the current study used three approaches (ADF, ADF GLS and PP) for testing the stationarity of the variables and suggested that all the variables are integrated as first difference as indicated by table 1 , and can be represented as I(1). Thus the maximum order of integration is 1 , hence $d_{\max }=1$. The second step in the TY procedure is the estimation of optimal length of lag selection (K). The optimal length of lag is selected by using various information criterion, current study three information criterion (i.e. AIC, SC and $\mathrm{HQ}$ ) to predict the optimal lag length $(K)$. The results in table 2 show that three information criteria (i.e. AIC, SC and $\mathrm{HQ}$ ) suggest 3 lags as optimal length of lag, thus $K=3$ in the current case. The third step of

DE GRUYTER OPEN
Timisoara Journal of Economics and Business | ISSN: 2286-0991 | www.tjeb.ro Year 2015 | Volume 8 | Issue 1 | Pages: 103 - 136 
Ahmad, F. (2015).

Determinants of Savings Behavior in Pakistan: Long Term- Short Term Association and Causality

TY approach is the estimation of VAR model at augmented optimal lag of $P=K+d_{\max }(4=3+1)$ and the in the final step Wald test of Granger casualty is conducted, results are given in Table 10.

Table 10. Long Run Granger Causality Test Results (Wald Test)

\begin{tabular}{ccc}
\hline Dependent variable: PRIVATE SAVINGS & & \\
\hline Excluded & Chi-sq & Probability \\
\hline GDP per capita & 6.62 & 0.0540 \\
Inflation rate & 0.63 & 0.8905 \\
Financial development & 2.29 & 0.0547 \\
Dependency ratio & 6.06 & 0.0985 \\
Exchange rate & 0.63 & 0.8907 \\
Industrial Production & 2.86 & 0.4137 \\
M2 & 3.48 & 0.3234 \\
Fiscal Balance & 6.24 & 0.0105 \\
\hline
\end{tabular}

Source: Author's calculations.

The results in Table 10 suggest that four variables exhibit long run association with the savings. The results confirms the findings of VECM that GDP per capita and financial development have long run association with savings, whereas also dependency ratio and fiscal deficit has long run association with the savings. Thus the results of the Wald test suggest that GDP per capita, financial development, dependency ratio and fiscal deficit granger causes changes in the savings level in the long run at $10 \%$ significance level and can be used to bring changes in the private savings in long run.

\section{Conclusions and Policy Related Implications}

The aim of the current study was to investigate the explanatory power of eight macroeconomic variables as determinants of private savings in Pakistan. This study used GDP per capita, inflation rate, financial development, dependency ratio, exchange rate, industrial production, M2 and fiscal deficit as explanatory variables. Time series data was used from the period of 1972 to 2012, providing 42 years data for the analysis. The four explanatory variables i.e. CPI, GDP, per capita and unemployment are extensively used in the existing studies that used Pakistan data for analysis, whereas financial development, dependency ratio and fiscal deficit are not used in the studies conducted in Pakistan. From an econometric point of view the existing studies have mostly investigated the long run and the short run association between determinants and private savings, whereas no known study has examined the both long run and short run causality between the determinants and private savings in the same study. The current study investigates the both the long run and the short run association of determinants

DE GRUYTER OPEN
Timisoara Journal of Economics and Business | ISSN: 2286-0991 | www.tjeb.ro Year 2015 | Volume 8 | Issue 1 | Pages: 103 - 136 
Ahmad, F. (2015).

Determinants of Savings Behavior in Pakistan: Long Term- Short Term Association and Causality

with private savings; and long run and short run causality between determinants and private savings. The current study employed the long run Johansen-Juselius co-integration model and VECM to examine the long run and short run association respectively and employed the Toda Yamamoto technique and the Granger causality test to check the long run and short run causality between determinants and private savings.

The analysis of the study started with the log transformation of all variables to remove the problem of heteroskedasticity. The stationarity of all variables are checked and we found that all variables are integrated at first difference. The VAR model is applied to get the optimal lag length by using AIC, SC and $\mathrm{HQ}$ and suggested the 3 optimal lag length for the co-integration. The J-J co-integration test was conducted at the optimal lag length of 3 and provided the presence of 9 unique co-integrating vectors among selected variables at the significance level of $5 \%$. This further suggested that the long run association exists between explanatory variables and private savings. In order to capture the long run association first normalized equation was used. The first normalized equation suggests six significant positive long run associations of GDP per capita, financial development, dependency ratio, exchange rate, industrial production and fiscal deficit with private savings and one negative significant associations of M2 with savings.

The VECM results suggest that two variables i.e. GDP per capita and financial development captures the short run changes in the private savings or can influence the private savings rate in the short run. The results suggested that both per capita and financial development have negative impact on private savings on short run. It concludes that in the short run growth in per capita and increased lending of financial institutions leads to the decline in private savings rate because of the availability of funds in the future through the increase in individual income and opportunity of borrowing in the economy. Furthermore, in VECM statistical significance and size of the ECT provides the extent and tendency of each explanatory variable to return back to its long run equilibrium position. The results of VECM suggest that four explanatory variables have the ability to return to their long run equilibrium position. The inflation rate, dependency ratio, exchange rate and fiscal development have the ability to return to their long run equilibrium position, thus they can be used to bring changes in the private savings in the long run.

The current study further found that in the short run financial development and dependency ratio Granger causes the changes in private savings rate, where as in the long run GDP per capita, financial development, dependency ratio and fiscal deficit causes changes in the private savings rate.

The findings of the current study have policy related implications in raising the level of private savings in Pakistan. The government can use the GDP per capita, inflation rate, financial development, dependency ratio and fiscal deficit in the long run and the short run to influence the level of private savings. The government or regulatory authorities such as the State Bank of

DE GRUYTER OPEN
132

Timisoara Journal of Economics and Business | ISSN: 2286-0991 | www.tjeb.ro

Year 2015 | Volume 8 | Issue 1 | Pages: 103 - 136 
Ahmad, F. (2015).

Determinants of Savings Behavior in Pakistan: Long Term- Short Term Association and Causality

Pakistan can facilitate the financial institution to offer new savings products or investment opportunities in the market by liberalizing the rules to stimulate the private savings. The amount saved can be used to invest in the country which will result in the economic growth and increase in the per capita income. In order to boost economic growth government should mobilize its resources to motivate private savings and reinvestment of the savings in profitable projects to further increase the income and saving rate.

The government and regulatory authorities should carefully monitor the lending of funds in the economy. The rules must be developed in order to ensure only lending to the high growth projects and government should motivate lending only for the investment in projects and business not for the personal use. Because lending for personal consumption or use reduces the private savings. The financial development in the economy reduces the savings rate, thus regulatory authorities can increase the deposits rate to motivate the private savings and can increase the borrowing rate for private use other than businesses or small projects. This will motivate the savings and discourage the borrowing for personal use. Similarly to motivate the workers and other employed individuals who are close to the retirement or want to save for after retirement consumption, the government can start any old age benefit plans or can direct financial institutions to start such schemes to promote savings. The funds deposited by the individuals can be used to finance projects and investments which lead to the growth in economic activities and income of individuals. Similarly governments can also stimulate the economic activities by investing in the infrastructural developmental projects, energy generation projects and industry support programs which will help improving the GDP growth rate and other economic indicators in Pakistan.

The government should also keep its fiscal deficit under control and should plan for recovering its deficit by carefully investing the amount in profitable projects. The relationship between fiscal deficit and savings suggest that individual save more to cover the fiscal deficit not for the investment purpose. Thus government should overcome this fear of individuals by decreasing its deficit by making investments in profitable projects. Similarly, Pakistan government borrowed money from the IMF, the World Bank and other countries to cover its fiscal deficit which put more pressure on the individuals by increasing the inflation in the economy because of increase demand of dollars for the repayment of loans and by the currency printing by the government to cover up the fiscal deficit. All these steps reduce the confidence in the private investor and saver in the economy and individual does not invest or save in the country. Thus government should properly control its fiscal deficit and must take measures to finance its deficit without affecting the confidence of the investor in the economy.

In the short run government can increase the private savings by decreasing the financial development, increasing deposit rates and lending rates and by offering attractive programs relating the old age benefits. This leads to the current savings by the individuals to meet the future consumption and investment needs. The government can also provide the incentives to

DE GRUYTER OPEN
Timisoara Journal of Economics and Business | ISSN: 2286-0991 | www.tjeb.ro Year 2015 | Volume 8 | Issue 1 | Pages: 103 - 136 
Ahmad, F. (2015).

Determinants of Savings Behavior in Pakistan: Long Term- Short Term Association and Causality

industries in the form of taxes' and duties' reduction to stimulate the growth in production and earnings of the firms and individuals. The government should provide protection to all the private savers against theft, fear of inflation and collapse of financial system and should reward the savers. This can be done by strengthening the local financial institutions, controlling the inflation rate and increasing the role of market signals in deciding the allocation of savings and investment.

\section{References}

Agrawal, P. (2001). The Relation between Savings and Growth: Cointegration and Causality Evidence from Asia. Applied Economics, 33, 499-513.

Ahmad, M., \& Asghar T. (2008). Estimation of Saving Behaviour in Pakistan Using Micro Data. The Lahore Journal of Economics, 9(2), 73-92.

Ahmed, M. H., Atiq Z., Alam, S., \& Butt, M. S. (2006). The Impact of Demography, Growth and Public Policy on Household Saving: A Case Study of Pakistan. Asia-Pacific Development Journal, 13(2), 57-71.

Ang, J. (2009). Household Saving Behaviour in an Extended Life Cycle Model: A Comparative Study of China and India. Journal of Development Studies, 45(8), 1344-1359.

Athukorala, P.-C., \& Kunal, S. (2003), The Determinants of Private Savings in India. World Development, 32(3), 491-503.

Azam, M., \& Shakeel, K. (2012). Impact of Foreign Capital Inflows on Household Saving in Pakistan. European Journal of Scientific Research, 68(3), 345-351.

Cardenas, M., \& Andreas, E. (1998). Saving Determinants in Colombia: 1925-1994. Journal of Development Economics, 57(1), 5-44.

Carroll, C. (1992). The Buffer-Stock Theory of Saving: Some Macroeconomics Evidence. Brookings Papers on Economic Activity, 2, 61-156.

Chaudhry, I. S., Faridi, M. Z., Abbas, M., \& Bashir, F. (2010). Short Run and Long Run Saving Behavior in Pakistan: An Empirical Investigation. Journal of Money, Investment and Banking, 16, 57-66.

Cohn, R. C., \& Kolluri, B., R. (2003). Determinants of Household Saving in the G-7 Countries: Recent Evidence. Applied Economics, 35(10), 1199-1208.

Deaton, A. S. (1991). Saving and Liquidity Constraints, Econometrica, 59(5), 1221-1248.

Doshi, K. (1994). Determinants of Saving Rate: An International Comparison. Contemporary Economic Policy, 12(1), 37-45.

Dusenberry, J. (1949). Income, Saving, and the Theory of Consumer Behavior. Cambridge, Harvard University Press.

Engle, R. F., \& Granger, C. W. J. (1987). Co-integration an Error Correction Representation, Estimation, and Testing. Econometrica, 55, 251-276.

Farhan, M., \& Akram, M. (2011). Does Income Level affect Saving Behaviour in Pakistan? An ARDL Approach to Co-integration for Empirical Assessment, Far East Journal of Psychology and Business, 3(3), 62-72.

Gujarati, D. N. (2003). Basic Econometrics. McGraw-Hill, New York.

DE GRUYTER OPEN
Timisoara Journal of Economics and Business | ISSN: 2286-0991 | www.tjeb.ro

Year 2015 | Volume 8 | Issue 1 | Pages: 103 - 136 
Ahmad, F. (2015).

Determinants of Savings Behavior in Pakistan: Long Term- Short Term Association and Causality

Haque, N. U., Aasim M. H, \& Peter, J. M. (1994). An Empirical Dependent Economy Model for Pakistan. World Development, 22, 1585-1597.

Hayek, F A. (1932). A Note on the Development of the Doctrine of Forced Saving. Quarterly Journal of Economics, 47, 123-133.

Hondroyiannis, G. (2004). Estimating Private Savings Behaviour in Greece. Journal of Economic Studies, 31(5), 457-476.

Hondroyiannis, G. (2006). Private Saving Determinants in European Countries: A Panel Cointegration Approach. Social Science Journal, 43, 553-569.

Husain. A. H. (1996). Private Saving and Its Determinants: The Case of Pakistan. The Pakistan Development Review, 35(1), 49-70.

Ibrahim, M. H. (2006). Stock Prices and Bank Loan Dynamics in a Developing Country: The Case of Malaysia. Journal of Applied Economics, 9(1), 71-89.

Johansen, S., \& Juselius, K. (1990). Maximum Likelihood Estimation and Inference on Cointegration with Application to the Demand for Money. Oxford Bulletin of Economics and Statistics, 52, 169-210.

Jongwanich, J. (2010). The Determinants of Household and Private Savings in Thailand. Applied Economics, 42(8), 965-976.

Kassim, S., Abd Majid, M. S., \& Yusof, R. M. (2009). Impact of Monetary Policy Shocks on Conventional and Islamic Banks in a Dual Banking System: Evidence from Malaysia. Journal of Economic Cooperation and Development, 30(1).

Kazmi, A. A. (1993). National Savings Rates of India and Pakistan: A Macro Econometric Analysis. The Pakistan Development Review, 32(4), 1313-1324.

Kazmi, A. A. (2001). A Study on Saving Functions for Pakistan: The Use and Limitations of Econometric Methods. The Lahore Journal of Economics, 6(2), 57-101.

Keynes, J. M. (1936). The General Theory of Employment, Interest and Money", London, Macmillan, 1974 edition.

Khan, A. H., Hassan, L., \& Malik, A. (1992). Dependency Ratio, Foreign Capital Inflows and the Rate of Savings in Pakistan, The Pakistan Development Review, 31(4), 843-856.

Khan, A. H., Hassan, L., \& Malik, A. (1994). Determinants of National Saving Rate in Pakistan. Economica Internationale, 47, No. 4.

Khan, R. E. A., \& Hye, Q. M. A. (2010). Financial Sector Reforms and Household Savings in Pakistan: An ARDL Approach. African Journal of Business Management, 4(16), 34473456.

Lambert, R. D., \& Bert, F. H. (1963). The Role of Savings and Wealth in Southern Asia and the West. France, UNESCO.

Leland, H. E. (1968). Saving and Uncertainty: The Precautionary Demand for Saving. Quarterly Journal of Economics, 82, 465-473.

Larbi, D. A. (2013). The Long Run Determinants of Private Domestic Savings in Ghana: A Cointeration Approach. Journal of Economics and Sustainable Development, 4(4), 125-136.

Loayza, N., \& Shankar, R. (2000). Private Savings in India. The World Bank Economic Review, 14(3), 571-594.

Marwan, A. M. T., \& Ahmad, Z. B. (2012). Comparing Savings Behavior in Asia and Latin America: The Role of Capital Inflows and Economic Growth. The Journal of Developing Areas, 46(1), 113-131.

DE GRUYTER OPEN 
Ahmad, F. (2015).

Determinants of Savings Behavior in Pakistan: Long Term- Short Term Association and Causality

Masson, P. R., Tamin, B., \& Hossein, S. (1998). International Evidence on the Determinants of Private Saving. The World Bank Economic Review, 12(3), 483-501.

Munir, R. S., Maqbool, H., Sarwar, G., \& Shaheen, S. (2011). Effect of Workers' Remittances on Private Savings Behavior in Pakistan. Asian Economic and Financial Review, 1(3), 95-103.

Murshed, S. M., \& Robin, I. A. (2012). Financial Liberalization, Savings and the Banking Sector in Bangladesh. South Asia Economic Journal, 13(1), 69-83.

Ozcan, M., Asli G, \& Seda E. (2003). Determinants of Private Savings Behaviour in Turkey. Applied Economics, 35(12), 1405-1416.

Pesaran, H. M., \& Shin, Y. (1998). Generalized Impulse Response Analysis in Linear Multivariate Models. Economics Letters, 58, 17-29.

Pigou, A. C., (1943). The Classical Stationary State. Economic Journal, 53, 343-351.

Qin, D. (2003). Determinants of Household Savings in China and Their Role in Quasi-Money Supply. Economics of Transition, 11(3), 513-537.

Qureshi, M. Z. (1981). Household Saving in Pakistan: Some Findings from Time-Series Data. The Pakistan Development Review, 20(4), 375-397.

Ramsey, F. P. (1928). A Mathematical Theory of Saving. Economic Journal, 38, 543-559.

Sajid, G. M., \& Sarfraz, M. (2008). Savings and Economic Growth in Pakistan: An Issue of Causality. Pakistan Economic and Social Review, 46(1), 17-36.

Salotti, S. (2010). Global Imbalances and Household Savings: The Role of Wealth. The Social Science Journal, 47(1), 21-44.

Sarantis, N., \& Stewart, C. (2001). Saving Behaviour in OECD Countries: Evidence from Panel Cointegration Tests. The Manchester School, 69, 22-41.

Siddique, R., \& Siddique R., (1993). Household Saving Behaviour in Pakistan. The Pakistan Development Review, 32(4), 1 - 27.

Simleit, C., Keeton, G., \& Botha, F. (2011). The Determinants of Household Savings in South Africa. Studies in Economics and Econometrics, 35(3), 1-20.

Sims, C. A. (1980). Macroeconomics and Reality. Econometrica, 48(1), 1- 49.

Snyder, D. W. (1974). Econometric Studies of Household Saving Behaviour in Developing Countries: A Survey. Journal of Development Studies, 10(2), 139-154.

Syed, M., \& Iftekhar., A. R. (2012). Financial Liberalization, Savings and the Banking Sector in Bangladesh. South Asia Economic Journal, 13(1), 69-83.

Thanoon, M., A.-M., \& Baharumshah, A. Z. (2012). Comparing Savings Behavior in Asia and Latin America: The Role of Capital Inflows and Economic Growth. The Journal of Developing Areas, 46(1), 113-131.

Toda, H. Y., \& Yamamoto, T. (1995). Statistical Inference in Vector Auto Regression with Possibly Integrated Processes. Journal of Econometrics, 66, 225-250.

DE GRUYTER OPEN
Timisoara Journal of Economics and Business | ISSN: 2286-0991 | www.tjeb.ro

Year 2015 | Volume 8 | Issue 1 | Pages: 103 - 136 